\title{
The Prevalence and Control of Bacillus and Related Spore-Forming Bacteria in the Dairy Industry
}

\author{
Nidhi Gopal',2, Colin Hill',3, Paul R. Ross ${ }^{4}$, Tom P. Beresford ${ }^{1}$, Mark A. Fenelon ${ }^{1}$ and \\ Paul D. Cotter ${ }^{1,3 *}$ \\ ${ }^{1}$ Teagasc Food Research Centre, Cork, Ireland, ${ }^{2}$ School of Microbiology, University College Cork, Cork, Ireland, ${ }^{3}$ APC \\ Microbiome Institute, Cork, Ireland, ${ }^{4}$ College of Science, Engineering and Food Science, University College Cork, Cork, \\ Ireland
}

Milk produced in udder cells is sterile but due to its high nutrient content, it can be a good growth substrate for contaminating bacteria. The quality of milk is monitored via somatic cell counts and total bacterial counts, with prescribed regulatory limits to ensure quality and safety. Bacterial contaminants can cause disease, or spoilage of milk and its secondary products. Aerobic spore-forming bacteria, such as those from the genera Sporosarcina, Paenisporosarcina, Brevibacillus, Paenibacillus, Geobacillus and Bacillus, are a particular concern in this regard as they are able to survive industrial

OPEN ACCESS

Edited by: Javier Carballo, University of Vigo, Spain

Reviewed by: George-John Nychas, Agricultural University of Athens,

Greece

Learn-Han Lee,

Monash University Malaysia, Malaysia

*Correspondence:

Paul D. Cotter

paul.cotter@teagasc.ie

Specialty section This article was submitted to

Food Microbiology,

a section of the journal

Frontiers in Microbiology

Received: 04 September 2015

Accepted: 30 November 2015

Published: 21 December 2015

Citation:

Gopal N, Hill C, Ross PR,

Beresford TP, Fenelon MA

and Cotter PD (2015) The Prevalence and Control of Bacillus and Related

Spore-Forming Bacteria in the Dairy Industry. Front. Microbiol. 6:1418. doi: 10.3389/fmicb.2015.01418 pasteurization and form biofilms within pipes and stainless steel equipment. These single or multiple-species biofilms become a reservoir of spoilage microorganisms and a cycle of contamination can be initiated. Indeed, previous studies have highlighted that these microorganisms are highly prevalent in dead ends, corners, cracks, crevices, gaskets, valves and the joints of stainless steel equipment used in the dairy manufacturing plants. Hence, adequate monitoring and control measures are essential to prevent spoilage and ensure consumer safety. Common controlling approaches include specific cleaning-inplace processes, chemical and biological biocides and other novel methods. In this review, we highlight the problems caused by these microorganisms, and discuss issues relating to their prevalence, monitoring thereof and control with respect to the dairy industry.

Keywords: dairy, spoilage, aerobic, spore-forming bacteria, biofilms

\section{CURRENT AFFAIRS IN THE DAIRY INDUSTRY}

The dairy industry is a dynamic global business, which plays an important role in the sustainability of the economies of many countries. According to the International Dairy Federation (IDF), 748.7 million tons of raw milk was produced in 2011, of which cow's milk accounted for 620.7 million tons. Taking into account that dairy production has steadily been growing since 2000 (International Dairy Federation [IDF], 2013), it is not surprising that the Food and Agriculture Organization of the United Nations (FAO) estimated global raw milk production to be worth 292 billion USD in 2011, while trade in dairy products (such as cream, butter, cheese, whey, buttermilk, skim and whole milk powders, casein, yogurt, lactose, and infant formula) represented 69 billion USD. Meanwhile, in the European Union, raw milk, and dairy products were valued at 53.1 billion EUR, which accounts for 14\% of the total value of the EU agricultural output in 2011 
(Marquer, 2013). In 2013, according to the European Commission milk statistics, the estimated average milk yield across the EU-28 was 6.411 ton/head, with Denmark, Sweden and Finland having the highest average milk yield per cow (Eurostat website, 2013 - http://ec.europa.eu/eurostat).

With the abolition of milk quotas in April 2015, it is expected that milk producers across the EU will be facing new and demanding economic challenges. The European Commission, in its 'milk package' provisions, has already anticipated that there will be a potential increase in milk production, especially across quota-bound countries such as Ireland, Germany, the Netherlands, Denmark, Austria, Poland, and France (European Commission, 2014). Consequently, with the favorable trade in milk and more prominent consumption of dairy products across households, it is anticipated that dairy ingredients will be generated on a much larger scale to meet these growing demands. However, to match up with the high-scale production, it is essential for processors to ensure that processing capacity meets the expected increased milk supply without comprising on quality and customer expectations. Therefore, quality issues affecting the dairy industry will need to be assessed and addressed to maintain product quality and safety. The continued control of Bacillus and related spore-forming bacteria will be key in this regard.

\section{DETERMINING THE QUALITY OF MILK}

Milk present in healthy udder cells is sterile (Tolle, 1980). However, it can subsequently become contaminated via different sources such as the external surfaces of animals or from other environments during milking, transport, storage, or processing. An amalgam of different factors, such as composition, udder health and hygiene, are assessed to determine the quality of raw milk (O’Brien et al., 2009).

Milk quality, good hygiene, and farm management practices are frequently monitored according to total bacterial count (TBC) testing of the product and relates to the total number of living bacteria per $\mathrm{ml}$ of milk. A failure to refrigerate appropriately (Blowey and Edmondson, 2010) can also lead to an increase in TBC. The legal TBC limit in farm raw milk is set at 100,000 cells $/ \mathrm{ml}$ (based on a geometric average over 2 months with at least two tests per month) across the EU and the Americas, with most farms striving for a desirable and achievable count of around 10,000 cells/ml (derived from Hillerton and Berry, 2004). In the dairy industry, it can be assumed that any grade $A$ unpasteurized milk that has a TBC of less than 100,000 cells/ml will be cleared of pathogenic and most non-pathogenic bacteria during pasteurization (Pantoja et al., 2012). Among the other microbiology-based tests that are carried out to assess the quality and safety of milk and resultant dairy products, are those designed to quantify thermoduric populations and specific pathogens, such as B. cereus. Whilst the monitoring and control of foodborne pathogens is traditionally performed using culturedependent approaches and standard biochemical identification, the advent of rapid, highly specific and highly sensitive detection methods has resulted in time-efficient, labor-saving, and reliable approaches (Mandal et al., 2011; Chapela et al., 2015; Law et al., 2015). These rapid methods are divided into three specific categories - nucleic acid-based assays, immunological methods, and biosensors (Mandal et al., 2011). Thus, controlling the levels of Bacillus and related spore-forming bacteria is key.

\section{Bacillus AND RELATED SPORE-FORMING BACTERIA AND THE DAIRY INDUSTRY}

As milk is highly nutritious and has a near neutral $\mathrm{pH}$ and high water activity, it provides an ideal environment for the proliferation of microorganisms (Quigley et al., 2013a). The microbiota of raw milk is rather complex, with the microbial community differing in response to hygiene, seasonality, animal species, animal health, and a variety of other factors (Quigley et al., 2013b). Of the microorganisms that can enter into the milk chain on farms or through dairy processing lines, the spore-forming bacteria are a particular concern as they have the ability, when in the spore form, to withstand harsh environmental conditions (Logan and De Vos, 2009; Postollec et al., 2012). Spore-formers are a primary cause of concern for manufacturers of powdered dairy ingredients and can be sub-categorized as being thermophilic, mesophilic or psychrotolerant in nature, with thermophilic spore-formers being more prevalent in the end product. The US Dairy Export Council has set strict tolerances for mesophilic ( $<1000 \mathrm{cfu} / \mathrm{g})$ and thermophilic spores $(<500 \mathrm{cfu} / \mathrm{g})$ in dairy powders and hence, understanding the factors that lead to their proliferation and survival within processing plants is necessary to control and reduce their presence (Watterson et al., 2014).

Unfortunately, spore-forming bacteria are ubiquitous bacteria commonly found in the soil as well as being natural colonizers of the gastrointestinal tract of insects and warm-blooded animals (Postollec et al., 2012). They are Gram-positive organisms encompassing more than 200 species that are capable of forming endospores, which make them resistant to extreme conditions such as pressure, extreme heat or cold, drought, starvation, biocides, and UV irradiation (Moeller et al., 2008). Spore-forming bacteria belong to the phylum Firmicutes, which can further be divided into five distinct classes: Bacilli, Clostridia, Erysipelotrichia, Negativicutes, and Thermolithobacteria (Galperin, 2013; Zhang and Lu, 2015). Even with constant evolution and re-classifications, the Bacilli and Clostridia remain the most dominant classes within the Firmicutes phylum, consisting of 16 and 21 families, respectively (Galperin, 2013) and are arguably the most important classes that are relevant to the dairy industry.

Anaerobic spore-forming bacteria of the Clostridium genus, especially C. botulinum and C. perfrigens, are thought to be the most lethal foodborne microorganisms due to the array of potent toxins and neurotoxins they produce. The prevalence and significance of Clostridium sp. in the dairy industry has recently been reviewed by Doyle et al. (2015) and will, therefore, not be the focus of further discussion in this review. Meanwhile, the aerobic spore-forming bacteria (Bacillus and related genera) 
greatly impact on quality, food safety, and the economy due to their spoilage-causing capabilities and to a lesser extent, diseasecausing potential. In an attempt to give an insight into this broad area, the following genera will be briefly described in this review: Bacillus, Geobacillus, Paenibacillus, Brevibacillus, Sporocarcina, and Paenisporosarcina.

\section{The Bacillus Genus}

The Bacillus genus, part of the Bacillaceae family, is probably the oldest and most diverse genus of bacteria. As per the review of Slepecky and Hemphill (2006), Bacillus sp. have a remarkable range of physiological characteristics that renders appropriate categorization and generalizations impossible. Although their main habitat has always been considered to be the soil, it is now being suggested that soil may simply act as a reservoir for Bacillus sp. (Hong et al., 2009). Indeed, it would seem that their expansive physiology has allowed these species to colonize almost all natural environments including soil, air, lake sediments, water, and fodder as well as extreme environments such as thermal acid water, salt marshes, hot springs, sub-Antarctic soil, and diseased bee larvae (Claus and Berkeley, 1986).

Consisting of over 280 validly published species to date (LPSN www.bacterio.net), most members of this genus are considered non-pathogenic with only $B$. anthracis and $B$. cereus as outright exceptions. Nonetheless, an in-depth analysis into the Bacillus genus, by De Jonghe et al. (2010), has demonstrated that although species other than $B$. cereus have not been implicated in food poisoning cases, cellular assays have confirmed the production, and functionality of heat-labile toxins by Bacillus circulans, Bacillus lentus, B. subtilis (Beattie and Williams, 1999), Bacillus licheniformis (Beattie and Williams, 1999; Lindsay et al., 2000), Bacillus pumilus (Lindsay et al., 2000), and Bacillus amyloliquefaciens (Phelps and McKillip, 2002) and cereulideresembling toxins by B. licheniformis (Beattie and Williams, 1999; Salkinoja-Salonen et al., 1999; Mikkola et al., 2000; From et al., 2005; Taylor et al., 2005), B. pumilus (Suominen et al., 2001; From et al., 2005, 2007), B. amyloliquefaciens (Mikkola et al., 2004, 2007), Bacillus mojavensis (From et al., 2007), B. subtilis (Beattie and Williams, 1999; From et al., 2005), Bacillus simplex, Bacillus firmus, Bacillus megaterium (Taylor et al., 2005), B. circulans and B. lentus (Beattie and Williams, 1999).

\section{Bacillus cereus}

Most relevant to this review, therefore, is the pathogenic soil-dweller $B$. cereus that is commonly encountered in raw milk and subsequent dairy products. The various strains of this species produce several potentially pathogenic substances such as hemolysins, phospholipases $\mathrm{C}$, the emesis-causing toxin (Cereulide), enterotoxins, metalloproteinases, collagenases, and beta-lactamases (Turnbull et al., 2002). B. cereus has been linked to foodborne emetic and diarrheal syndromes and has been a known causative agent of food poisoning for more than 40 years (Ghelardi et al., 2002).

The emetic syndrome is caused by cereulide, which is synthesized by a non-ribosomal peptide synthetase that is encoded by the ces genes (Ehling-Schulz et al., 2005; Rajkovic et al., 2008). Cereulide is a small, heat-stable circular dodecadepsipeptide that has been shown to be toxic to mitochondria by acting as a potassium ionophore (Agata et al., 1995; Shinagawa et al., 1995; Mikkola et al., 1999), can cause cellular damage in animal models (Ehling-Schulz et al., 2005) and have an immunomodulating effect that can inhibit human natural killer cells (Paananen et al., 2002). The emetic toxin is produced by cells growing in the contaminated food (Kramer and Gilbert, 1989), and causes nausea and vomiting within 1-5 h of ingestion (Gilbert and Kramer, 1984; Schoeni, 2005). Although the exact number of $B$. cereus cells needed to produce adequate toxin to cause disease has not been determined, levels of $10^{3}-10^{10} \mathrm{CFU} \mathrm{g}^{-1}$ have been detected in foods, which have caused outbreaks (Gilbert and Kramer, 1986).

The diarrheal syndrome, on the other hand, is caused by, at least, three known heat-labile enterotoxins: hemolysin BL ( $\mathrm{Hbl}$; Beecher et al., 1995), non- hemolytic enterotoxin (Nhe; Granum et al., 1999), and cytotoxin K (CytK; Lund et al., 2000). Hbl and Nhe each consists of three individual protein subunits while CytK belongs to the family of $\beta$-barrel pore-forming toxins (Stenfors Arnesen et al., 2008). Vegetative cells that are ingested as viable cells or spores produce protein enterotoxins in the small intestine causing the diarrheal syndrome, a mechanism sometimes termed a toxicoinfection (Granum et al., 1993; Andersson et al., 1998; Clavel et al., 2004). The main symptoms of B.cereus-related diarrhea include abdominal cramps and watery diarrhea 8-16 h after ingestion (Ehling-Schulz et al., 2005). The infective dose of the diarrheal disease has been described as ranging between $10^{5}$ and $10^{8} \mathrm{CFU} \mathrm{g}^{-1}$ of food although lower and much higher counts of viable cells or spores have also been reported (Gilbert and Kramer, 1986).

Bacillus cereus strains are able to survive industrial pasteurization processes due to the production of spores while psychrotrophic strains are able to survive refrigeration temperatures, and can affect the shelf-life of pasteurized milk and cream (Griffiths, 1992). Studies into the prevalence of aerobic spore-formers in raw milk have demonstrated that aerobic spore counts fluctuate with seasonal changes, with higher counts in the summer when cows are kept grazing outdoors as compared to the winter when cows are kept indoors (Christiansson et al., 1999). B. cereus is potentially the only food-poisoning causing pathogen in the Bacillus genus, but, several other species have been recognized as being the cause of bacterial spoilage of milk and milk products. Irrespective of seasonal, regional and methodological fluctuations, the microbiota of raw milk shows a few general trends - psychrotolerant strains of $B$. cereus are the predominant species in raw milk in the summer period (Scheldeman et al., 2006); B. licheniformis, $B$. pumilus, and B. subtilis represent the principal mesophilic spore-forming species (Phillips and Griffiths, 1986; Sutherland and Murdoch, 1994; Tatzel et al., 1994; Lukášová et al., 2001) while thermotolerant strains of $B$. licheniformis are the most prevalent thermophilic or thermotolerant species (Phillips and Griffiths, 1986).

\section{Bacillus licheniformis}

Bacillus licheniformis, alongside B.cereus, has been shown to be one of the most prevalent Bacillus species encountered in raw 
milk and along the dairy processing continuum (KalogridouVassiliadou, 1992; Scheldeman et al., 2006). Although, $B$. licheniformis is not categorized as a human pathogen, the spores of the bacterium are known to cause spoilage of milk and dairy products, raise specification compliance problems and have adverse effects on milk organoleptic and functional properties (Crielly et al., 1994; Dhakal et al., 2014). Previous studies have demonstrated that $B$. licheniformis strains encountered in dairy foods show extensive genetic heterogeneity, with the high prevalence in the dairy industry attributed to contamination from external sources such as soil and silage as well as sources intrinsic to dairy processing factories (Rückert et al., 2004; Scheldeman et al., 2005; Dhakal et al., 2013). B. licheniformis is often associated with milk powders that have a low spore count due to its inability to form biofilms and is also known to be among spore-formers capable of producing spoilage enzymes (De Jonghe et al., 2010; Reginensi et al., 2011).

Bacillus licheniformis was the second most common thermophilic spore-former detected in a survey of 28 milk powder samples sourced from 18 different countries, with a total occurrence of 39.2\% (Rückert et al., 2004). The same study highlighted the presence of a specific B. licheniformis strain in 27 out of the 28 milk powder samples, indicating its ubiquity as a common soil isolate (Rückert et al., 2004). Studies into the seasonal effects of the bacterial flora of farms in the Midwest, USA (bulk tank milk, environment, and corn silage) identified that $B$. licheniformis was the predominant species in summer $(49.4 \%)$ as well as in winter (62\%), albeit having lower numbers in summer (Buehner et al., 2014). In line with other studies, infant milk formula (IMF) and whole milk powders sampled from diverse manufacturers in China identified B. licheniformis as the most prevalent thermophilic bacilli in Chinese milk powders, with an occurrence of $36.8 \%$ out of 801 isolates (Yuan et al., 2012). The high prevalence of B. licheniformis in milk samples is potentially attributed to its widespread distribution in the environment and across the dairy farms, e.g., feed concentrate, fecal matter, soiled udders and teats, raw milk as well as from factory-derived contamination (Vaerewijck et al., 2001; Rückert et al., 2004; Scheldeman et al., 2005; Reginensi et al., 2011).

\section{Bacillus thuringiensis}

Bacillus thuringiensis forms part of the $B$. cereus group of bacteria (B. cereus sensu lato) and is known to be biochemically identical to $B$. cereus sensu stricto. The bacteria is known to produce similar enterotoxins as $B$. cereus sensu stricto, with some commercially used strains known to have genes for $\mathrm{Hbl}$, Nhe, and CytK (Kim et al., 2014). However, due to the fact that standard methods for detection and enumeration (ISO7932 and ISO21871) in food and clinical settings do not differentiate between the two species, the occurence of outbreaks due to B. thuringiensis is often underestimated (Anonymous, 1997; European Food Safety Authority, 2005; Kim et al., 2014). Despite its known pathogenicity, B. thuringiensis has only been implicated in one confirmed case of food poisoning even though it has previously been isolated from a variety of food products including milk, farm bulk tank and creamery silo milk indicating the potential attribution of outbreaks to $B$. cereus sensu stricto rather than the actual B. thuringiensis (Phillips and Griffiths, 1986; Jackson et al., 1995; Damgaard et al., 1996). For years, commercial preparations of $B$. thuringiensis have been used as biological insecticides, since it is an entomopathogen capable of producing several insecticidal proteins (Lemes et al., 2015). Hence, spraying of agricultural crops with $B$. thuringiensis preparations to protect against insect infestations is common, raising the question of the prevalence of enterotoxins that are pathogenic to humans, should the bacterial preparations persist upon consumption.

\section{Other Bacillus sp.}

Other Bacillus species such as B. weihenstephanensis, B. pumilus, and $B$. subtilis often isolated from milk and farm environments have been reported to either produce putative cereulide, the emetic toxin produced by $B$. cereus or other enterotoxic substances that can be harmful to humans (Nieminen et al., 2007; Yoo et al., 2014). B. weihenstephanensis is a psychrotolerant bacterium known to cause spoilage but its pathogenicity has yet to be elucidated (Thorsen et al., 2006; Hoton et al., 2009; Stenfors Arnesen et al., 2011). B. pumilus is not known to commonly cause human infections but has previously been isolated from mastitic milk samples in Finland (Nieminen et al., 2007; CaamañoAntelo et al., 2015). B. subtilis, on the other hand, although not traditionally categorized as a human pathogen, has been reported to be involved in food poisoning cases, e.g., in a 2005 outbreak in a kindergarten caused by milk powder, with vomiting being the most common symptom but is often accompanied by diarrhea (Pavic et al., 2005; Logan, 2012). However, it is believed that outbreaks caused by B. weihenstephanensis, B. pumilus, and $B$. subtilis are often attributed to $B$. cereus, unless further in-depth microbiological identifications are initiated (Logan, 2012). Another spore-forming bacterium encountered globally in milk products is the highly heat resistant spore-producing B. sporothermodurans (Pettersson et al., 1996). The occurrence of $B$. sporothermodurans has mostly been identified in indirectly UHT-processed milk and affected milk products ranged from whole, skimmed, evaporated, or reconstituted UHT milk to UHT cream, chocolate milk, and milk powders (Hammer et al., 1995; Klijn et al., 1997).

Because of their ubiquity in nature, the actual source of contamination by Bacillus sp. on dairy farms can seldom be determined exactly and is probably a cumulative process as raw milk is extracted, processed, transported, and stored. Most common contamination sources include soil, bedding material, silage, feces, rinse water from milking equipment, and feed (Christiansson et al., 1999; Magnusson et al., 2007). Once raw milk is contaminated by these spoilage species, the entire milk processing continuum is affected since some Bacillus sp. produce highly hydrophobic spores that can firmly adhere to inert materials used in food processing, e.g., stainless steel and polymers to form multicellular structures called biofilms (Wiencek et al., 1991; Hüsmark and Rönner, 1992). Once attached to manufacturing plants, these biofilms become a reservoir of spores, which act as the main contamination source of final dairy products indicating poor plant hygiene (Burgess et al., 2013). In the last section of this review, we address in greater detail the issue of biofilm formation. 


\section{The Geobacillus Genus}

The genus Geobacillus was established by Nazina et al. (2001) following reclassification of the thermophilic bacilli of genetic group 5 (group 5 is one of the five phylogenetically distinct clusters of Bacillus, based on 16S rDNA sequence alignment; Ash et al., 1991; Rainey et al., 1994; Xu and Côté, 2003; Kuisiene et al., 2004). Part of the Bacillaceae family, Geobacillus comprised of 19 species and four sub-species at the time of writing (LPSN www.bacterio.net). Various investigations have shown that Geobacillus strains are wide spread in the environment, having been isolated from high-temperature environments such as geothermal features or sub-surface layers of high-temperature oil fields as well as cooler environments, e.g., cool soil samples or hay compost (Sung et al., 2002; Banat et al., 2004; Marchant and Banat, 2010).

Geobacillus sp. are known to be among the most common contaminants of milk powders. As an obligate thermophile that grows at temperatures ranging between 48 and $60^{\circ} \mathrm{C}$, Geobacillus is able to survive industrial pasteurization of raw milk and subsequently, spores adhere to surfaces and germinate to form biofilms, resulting in spoilage of milk products (Murphy et al., 1999; Seale et al., 2012). Although not pathogenic, members of this species and most importantly the aforementioned, Geobacillus stearothermophilus, is a proven problematic sporeforming bacterium encountered in whole and skim milk powders produced across the world (Rückert et al., 2004). An RAPDbased (random amplified polymorphic DNA) survey by Rückert et al. (2004) established that G. stearothermophilus accounted for $10.8 \%$ of all isolates (742) tested in milk powders originating from Poland, Germany, Netherlands, Great Britain, USA, Mexico, Chile, South Africa, Australia, and New Zealand. Meanwhile, a survey undertaken at a whole milk powder manufacturing plant in New Zealand reported that Geobacillus sp. were able to colonize all stages of the manufacturing process (evaporators, surface heaters, homogeniser, and vibrofluidiser) apart from the pre-heating process (Scott et al., 2007). The same study also highlighted that Geobacillus sp. was the predominant thermophilic spore type isolated from foulant samples collected from different sites of the processing stages after a manual shutdown, indicating a potential source of inoculum for Geobacillus sp. (Scott et al., 2007).

Geobacillus strains were also isolated from a biodiversity survey looking at spoilage and non-spoilage associated aerobic spore-formers in dairy processing and food products (Lücking et al., 2013). In this study, Geobacillus sp. represented $10 \%$ of the 467 investigated isolates with G. stearothermophilus (41 isolates) being the most prevalent Geobacillus strain followed by G. pallidus (five isolates) and G. thermoleovorans (two isolates; Lücking et al., 2013). Zhao et al. (2013), in their investigation into biofilms formed by thermophilic spore-formers, affirmed that the most potent biofilm-forming Geobacillus strains isolated from the dairy industry are G. stearothermophilus and G. thermoglucosidans. The study showed that Geobacillus species have greater ability to form biofilms at air-liquid interfaces rather than submerged surfaces, with the most stable sporeproducing $G$. thermoglucosidans requiring proteolytic input from other spoilage organisms to thrive (Zhao et al., 2013).
However, although Geobacillus sp. are common contaminants encountered in the dairy industry, not many reproducible genotypic assays to differentiate between different strains and their potential sources exist as routine testing relies on biochemical differences (Seale et al., 2012). Even though previous studies have used random amplification of polymorphic DNA PCR (RAPD_PCR) to genotype Geobacillus sp., poor reproducibility and inaccurate interpretation of banding patterns render the technique questionable (Seale et al., 2012). Other approaches such as genotyping of specific housekeeping genes have also been trialed but without much success, highlighting the need for research into novel genotypic assays (Durak et al., 2006).

\section{The Paenibacillus Genus}

The Paenibacillus genus was coined by Ash et al. (1993) following a thorough investigation into the $16 \mathrm{~S}$ rRNA gene sequences of 51 species of the Bacillus genus (Ash et al., 1991). This genus is now part of the Paenibacillaceae family and currently comprises of 154 named species (LPSN www.bacterio.net). The type species is Paenibacillus polymyxa (LPSN www.bacterio.net). Normal environments of Paenibacillus strains include soil, the rhizosphere of plants, water, diseased insect larvae, and food products (Daane et al., 2002; Ahn et al., 2014). As highlighted in a review by Heyndrickx and Scheldeman (2002), low numbers of Paenibacillus spores can be found in both raw and pasteurized milk. Although there had been no previous reports of these spores surviving industrial sterilization or UHT processing of milk, Paenibacillus lactis has been isolated directly from raw and UHT milk as well as from the dairy farm environment (Scheldeman et al., 2004). In that particular study, P. lactis was isolated in conjunction with B. sporothermodurans, a bacterium that produces endospores capable of resisting ultra-high temperature (UHT) and industrial sterilization processes (Heyndrickx et al., 2012). The simultaneous isolation of these two species indicates that Paenibacillus is also capable of resisting UHT and go on to have an impact on food safety and quality (Scheldeman et al., 2004). In the dairy farm environment, the most common sources of raw milk contamination with Paenibacillus strains are silage and feed concentrate for cattle (Vaerewijck et al., 2001; te Giffel et al., 2002).

Alongside Bacillus sp., Paenibacillus sp. has been classified as being an essential limiting factor in the shelf-life of high temperature short time (HTST) pasteurized fluid milk due to their ability to survive HTST pasteurization regimens as well as thrive at refrigeration temperatures (Fromm and Boor, 2004; Durak et al., 2006; Huck et al., 2007, 2008). A real-time PCRbased investigation into pasteurized fluid milk products by Ranieri et al. (2012) has indicated that, once post-pasteurization contamination is excluded, Bacillus sp. is more prevalent in raw milk and at early stages of shelf-life ( $<7$ days). Meanwhile, Paenibacillus sp. is highly prevalent (over 95\% of the bacterial population) late in shelf-life ( $>10$ days; Ranieri and Boor, 2010) as they are psychrotolerant and grow extensively during refrigerated storage. However, due to the lack of appropriate molecular-based rapid detection assays for spoilage microorganisms such as Paenibacillus sp., it is only recently that Paenibacillus has been characterized as the predominant fluid 
milk spore-forming spoilage genus (Fromm and Boor, 2004; Huck et al., 2008; Ranieri and Boor, 2009; Ivy et al., 2012).

\section{Other Related Genera}

The Brevibacillus genus was established by Shida et al. (1996) following genetic reclassification of species belonging to the Bacillus brevis group and now forms part of the Paenibacillaceae family (Sanders et al., 2003). At the time of writing, this genus included 20 species with validly published names (LPSN www.bacterio.net). As far as milk spoilage is concerned, a few species of Brevibacillus have been encountered in 'commercially sterilized' milk, raw milk, silage and milking equipment (Logan et al., 2002; Scheldeman et al., 2005). A polyphasic taxonomic study of aerobic endospore-forming bacteria by Logan et al. (2002) isolated two strains of Brevibacillus agri (LMG 19651, LMG 19652) from samples of 'commercially sterilized' milk. Meanwhile, a molecular-based investigation (amplified ribosomal DNA restriction analysis, 16S rRNA gene sequencing, percent $\mathrm{G}+\mathrm{C}$ content and DNA-DNA reassociations) into 17 dairy farms in diverse locations across Belgium indicated the presence of $B$. agri (4.8\% of the total samples under investigation), B. borstelensis (7.2\%) and Brevibacillus sp. (4.8\%) in raw milk collected over a 5 -months period in the winter (Scheldeman et al., 2005). Low levels of $B$. borstelensis (17 isolates from four samples) were also detected in whole milk and skim milk powders in a Chinese study looking at whole, skim and infant milk powders (Yuan et al., 2012). Hence, Brevibacillus is often encountered in milk and milk products globally, albeit at low levels.

The Sporosarcina genus, established by Kluyver and van Niel (1936), forms part of the family of the Bacillaceae. At the time of writing, the genus comprised 12 species with Sporosarcina ureae being the type species (Yoon et al., 2001; Reddy et al., 2003; An et al., 2007; Kwon et al., 2007; Yu et al., 2008; Tominaga et al., 2009; Kämpfer et al., 2010; Wolfgang et al., 2012). Sporosarcina originate from and are able to thrive in a variety of environments, e.g., soil, seawater, pond water in the Antarctic, human blood, raw bovine milk or factory equipment used in the manufacture of soy sauce (Yoon et al., 2001; Kwon et al., 2007; Yu et al., 2008; Tominaga et al., 2009; Wolfgang et al., 2012). Meanwhile, the Paenisporosarcina genus was established by Krishnamurthi et al. (2009). At the time of writing, this genus comprised of four species. An investigation into environmental samples collected from a New York State dairy farm, using a developed culture-dependent selection strategy and an $r p o B$ sequence-based subtyping method, yielded only $0.2 \%$ of Sporosarcina sp. (Huck et al., 2008). Therefore, based on this study, the prevalence of Sporosarcina and Paenisporosarcina strains in foodstuffs and, more relevantly, milk, is not high when compared to other aerobic spore-formers.

\section{SPOILAGE OF MILK AND DAIRY PRODUCTS BY Bacillus AND RELATED GENERA}

Aerobic spore-forming bacteria are a major concern to the dairy industry, less for their pathogenicity but more for their spoilage-causing capabilities. Food safety and product quality are known to be affected by these microoorganisms by three different mechanisms - (i) production of toxins, (ii) production of spoilage enzymes, and (iii) affecting the production of secondary dairy products such as cheese, yogurt, and milk powders (De Jonghe et al., 2010). B. cereus is an example of a spore-former, commonly encountered in the dairy industry that is capable of causing food poisoning via the production of toxins as demonstrated in Section "Bacillus cereus."

\section{Production of Spoilage Enzymes}

Enzymes, indigenous or microbial, can either be beneficial or detrimental to the dairy industry. Raw milk originating from healthy udder cells already contains an array of indigenous enzymes (Andrews, 1991; Deeth and Fitz-Gerald, 1994). However, most of these enzymes do not affect food safety and product quality, with only proteases and lipases that extensively influence the value and quality of milk and milk products by impacting on sensory qualities such as texture, taste, aroma, and nutritional value (Teh et al., 2014).

On the positive side, indigenous milk proteases such as plasmin are essential for the manufacture of many cheeses while esterases or lipases impact on cheese flavor development by hydrolysing milk fat to free fatty acids (Somers and Kelly, 2002; Holland et al., 2005). Though enzymes produced by bacteria are mostly regarded as unfavorable, enzymes deriving from lactic acid bacteria (LAB) are of critical importance (Mensah et al., 1991) and influence sensory properties of products, especially flavor and texture in cheese and yogurt (Giraffa, 2014).

In contrast, spoilage enzymes encountered in the dairy industry originate from a range of bacteria, namely, Pseudomonas (Adams et al., 1975), Clostridium, Arthrobacter, Microbacterium, Streptococcus, Corynebacterium (Chen et al., 2003), Flavobacterium, Acinetobacter (Craven and Macauley, 1992) and most importantly, the order Bacillales which include the Bacillus, Paenibacillus, and Viridibacillus genera (Collins, 1981; Phillips et al., 1990; Moreno Switt et al., 2014). These microorganisms produce a variety of proteases, lipases, and phospholipases that impact on the texture of dairy products and cause typical off-flavors (Lücking et al., 2013). For example, $B$. cereus is known to cause off-flavors such as the "bitty cream" and "sweet curdling" as a result of its enzymatic activities. The "sweet curdling" defect, i.e., the curdling of milk without the addition of any acidifying agent is caused by the action of proteolytic enzymes while the "bitty cream" defect, which can be described as the floating of clumps of fat, is caused by lecithinase activity (Coorevits et al., 2010). Other off-flavors such as the bitter, fruity, or rancid defects as well as flat-sour spoilage are caused by the presence of an array of other microorganisms in pasteurized and intermittently, UHT milk. Consequently, bacterial enzymes are a major contributor to the spoilage of dairy products and hence, causing considerable economic losses.

\section{Production of Secondary Dairy Products}

Milk products have been manufactured for millennia to maintain a longer shelf-life. However, the quality and safety of dairy products are heavily dependent on the initial quality of raw 
milk as the prevalence of any defect or pathogen will most likely be increased during processing. With the global increase in consumption and demand of dairy products, it is essential for dairy manufacturers to strictly adhere to rules and regulations to meet quality control standards and customer requirements. Therefore, the presence of spore-forming bacteria in raw milk poses a major problem with respect to the production of secondary dairy products as they can give rise to several structural, chemical, and organoleptic defects.

\section{Yogurt}

Yogurt is one of the most highly consumed dairy products with, for example, an average production of 1938 million kilograms and consumption of 6.2 kilograms per capita in the US in 2011 (Clark et al., 2014). Although the main contaminants of yogurts are yeasts and molds, bacterial contamination by spore-forming bacteria resistant to industrial heat treatments, can gradually lead to deterioration of quality (MacBean, 2009). Common defects encountered in yogurts include high acid levels that produce a high acetaldehyde flavor (Vedamuthu, 1992), defects related to appearance and texture and, most relevant to this review, the incorporation of bitter flavors in the end product caused by proteinase activities of spore-forming bacteria such as $B$. cereus or B. subtilis (Mistry, 2001).

\section{Dairy Powders}

In contrast, microbial growth in powdered dairy ingredients is minimal because of their low water content (Chen et al., 2003). They can, nevertheless, become contaminated with thermoduric or thermophilic spore-forming bacteria during the manufacturing process. The vegetative cells and spores of these bacteria are able to survive pasteurization and may go on to form biofilms on the stainless steel surfaces of heat exchangers and evaporators (Flint, 1998). Contamination of the powdered ingredients occur sporadically, when fragments of the cells or biofilms are sloughed off and enter the processing stream affecting both product quality and limiting the run length of the processing plant (Flint et al., 1997b; Hinton et al., 2002). Even though most thermophilic bacteria do not go on to cause diseases (Scott et al., 2007), given most suitable conditions the dormant spores can germinate, producing acids, and enzymes that impact on the composition and organoleptic properties of the powders (Chen et al., 2004; Flint et al., 2007). In extreme cases of spore contamination, concentrations of up to $10^{5} / \mathrm{g}$ of milk have been detected, which far exceed typical specifications resulting in lower-value outof-specification products (Seale et al., 2008) that fail to meet customer requirements.

\section{Infant Milk Formula}

Infant milk formula is produced in such a way to mimic the composition of human milk in terms of nutrients and its production is regulated by the European Commission (1991) as well as the Codex Alimentarius Commission (2007). Powdered IMF is known to influence the development of the gut flora in newborn infants with sterile gastrointestinal tracts. Therefore, for the safety of infants, pathogens such as S. aureus, B. cereus,
C. perfringens, Enterobacteriaceae (coliforms), and Salmonella are screened for in all IMF production batches (Mackie et al., 1999; Forsythe, 2005).

To date, several bacterial genera such as Bacteroides, Bifidobacterium, Clostridia, Lactobacilli, Streptococci, Salmonella, Klebsiella, and Cronobacter have been reported in IMF (Stark and Lee, 1982; Benno et al., 1984; Harmsen et al., 2000; Forsythe, 2005). However, the literature focuses mainly on Cronobacter sakazakii, an emergent pathogenic contaminant of IMF that causes a life-threatening form of neonatal meningitis, bacteraemia, necrotising enterocolitis, and necrotising meningoencephalitis in healthy as well as premature and immuno-compromised infants (Muytjens et al., 1983; Iversen and Forsythe, 2003; Walsh et al., 2011). As far as spore-forming bacteria are concerned, the incidence of Bacillus sp., albeit at low levels, has been reported in IMF. An Italian study by Di Pinto et al. (2013), identified 11 (out of 60) positive IMF samples for Bacillus sp. with five characterized as $B$. cereus and the remaining being $B$. licheniformis, B. subtilis, and $B$. mycoides. Meanwhile, Lequin et al. (2005) studied three pre-term infants who suffered fatal hemorrhagic meningoencephalitis due to $B$. cereus infections, acquired from unknown sources. Therefore, taking into consideration that IMF can effectively harbor pathogenic microorganisms, it is essential to detect and control these bacteria for the safety of infants and children.

\section{Cheese}

Cheese is one of the most traded dairy products globally, with more than 8.4 million tons produced in the EU in 2011 (O'Sullivan et al., 2013). Milk, rennet and salt are the only staple ingredients in cheese production, but a variety of microbial interactions with these ingredients allow for the production of approximately a thousand cheese varieties (Fox and McSweeney, 2004; Fox et al., 2004; O'Sullivan et al., 2013). As a result of the intricate interactions between these microorganisms, cheese is probably one of the secondary products of milk that is mostly affected by spoilage bacteria with a range of factors involved in determining the spoilage. Depending on the spoilage microorganisms present, common cheese defects include taste and odor defects, biogenic amine (BA) formation, gas formation, secondary fermentations, mineral deposition, and cheese pinking (O’Sullivan et al., 2013).

The main defect in cheese involving spore-forming bacteria is late gas blowing. The latter is usually seen in Dutch or Swiss-type cheeses when spores of butyric acid bacteria germinate during cheese ripening and anaerobically ferment lactate to acetate, butyrate, carbon dioxide, and hydrogen (Sheehan, 2011, 2013). The production of BAs is another defect encountered in cheese. High concentrations of BAs have been detected in fermented and non-fermented foods products since an array of species from different genera can decarboxylate one or more amino acids (Maijala et al., 1995; Marino et al., 2000). Nonetheless, more relevant to this review is the fact that a few strains of Bacillus (B. subtilis, B. megaterium, B. licheniformis, B. amyloliquefaciens) have amine-producing capabilities (Zaman et al., 2010). These BAs can cause toxic reactions that are detrimental to health. Amine production cheese is prevalent due the availability of 
free amino acids after proteolysis, the presence of decarboxylasepositive microorganisms and suitable environmental factors (Burgess et al., 2010).

In summary, milk is a highly nutritious but perishable food product that can easily harbor a range of spoilage organisms. While contamination with non-spore-forming bacteria postpasteurization or due to inadequate heat treatments can easily be rectified, contamination with Gram positive thermophilic or psychrotolerant spore-forming bacteria cannot be eradicated due to their ability to survive industrial pasteurization regimens (Ivy et al., 2012). These spore-forming bacteria are abundant in dust, dairy-feed concentrates, silage and forages, therefore, easily colonize skin and hair of cattle and contaminate milk (Ledenbach and Marshall, 2010). Colonization of dairy manufacturing plants by Bacillus sp. and relatives give rise to a reservoir of contamination, in the form of biofilms, which result in spoilage and low quality products.

\section{BIOFILMS}

The complex process of biofilm formation and dissemination is responsible for the transmission of spoilage as well as pathogenic bacteria in the form of detached clumps and clusters (HallStoodley and Stoodley, 2005). Bacteria tend to form biofilms to allow survival in hostile environments. These microorganisms can attach to a wide range of surfaces as long as nutrients are available. Surfaces can include living tissues, in-dwelling medical devices, industrial or potable water system piping, stainless steel food processing equipment or natural aquatic systems (Donlan, 2002). Research has shown that biofilm formation is widespread in food and beverage industries due to the high availability of nutrients and organic components. Once these biofilms are established, they go on to cause substantial losses to industries in a variety of ways. Significantly, a number of food pathogens, including Listeria monocytogenes, B.cereus and Salmonella sp. are among those capable of forming biofilms (Chmielewski and Frank, 2003).

\section{The Effects of Biofilms in Dairy Processing Plants}

Milk is an ideal culture medium for both spoilage and pathogenic microorganisms, which go on to contaminate milk processing lines and dairy products. These microorganisms can contaminate either in the form of vegetative cells, spores, or detached biofilm clumps that adhere to the stainless steel components. Processing lines in dairy manufacturing plant are generally made of stainless steel as it matches the requirements of materials that come in contact with food. Even though stainless steel is the ideal material to use for equipment in dairy manufacturing plants, the aggregation, adherence, and contamination by biofilms cannot be prevented. Studies have established that dead ends, corners, cracks, crevices, gaskets, valves, and joint are all suitable areas for biofilm formation and, therefore, it is essential to use surfaces with minimal cracks and crevices to reduce bacterial adherence and biofilm formation (Storgards et al., 1999a,b; Bremer et al., 2009).
The most common aerobic thermophilic/thermoduric sporeformers identified across dairy manufacturing plants, and dairy products, belong to the Bacillus and Geobacillus genera, with B. licheniformis, B. coagulans, B. cereus, B. pumilus, and Geobacillus sp. (mainly G. stearothermophilus) being frequently identified in dairy biofilms (Flint et al., 1997a; Murphy et al., 1999; Parkar et al., 2001; Scott et al., 2007; Burgess et al., 2010; Shaheen et al., 2010; Yuan et al., 2012). As noted above, G. stearothermophilus is a non-pathogenic, aerobic sporeforming bacterium that is commonly isolated from contaminated milk products, especially milk powders but is only present at low levels in raw milk (Murphy et al., 1999). Several studies have demonstrated that the bacterial adhesion process can also be influenced by additional secondary factors. For example, bacteria such as $B$. cereus require additional milk components such as natural surfactants and phospholipids to colonize stainless steel equipment as it has been shown that certain strains of $B$. cereus can form biofilms in whole milk but not in water-diluted milk, probably due to the presence of surface-active compounds found in whole milk that act as a surfactant in biofilm formation (Shaheen et al., 2010). However, with respect to protein fouling, milk proteins, and milk aggregates can contribute to the growth of adherent bacteria as a consequence of being ideal substrates for bacterial growth, giving high specific growth rates and having the ability to sustain bacterial populations for a long period of time (Yoo et al., 2006). Investigations involving several species of Bacillus have established that the spore form of the bacterium attaches more readily than vegetative cells to stainless steel components as they have a relatively high hydrophobicity, are able to resist heat and chemicals and have greater solid surfacesadhering capabiities (Roberts and Hitchins, 1969; Rönner et al., 1990; Hüsmark and Rönner, 1992).

Once these biofilms have colonized the processing environments, it does not take long before they start to detach and disperse, leading to contamination of products. Biofilm detachment can occur by three different processes (i) erosion that occurs due to fluid shear forces; (ii) abrasion, which is the result of collision of particles and (iii) sloughing, which can be defined as the instant loss of large parts or the complete biofilm (Morgenroth, 2003; Garny et al., 2008). Given that biofilms can cause such a variety of potential hazards for the dairy industry, it is essential that companies maintain good hygienic practices and comply with high customer specifications, stringent biofilm monitoring and control strategies (McGuire and Kirtley, 1989; Flint et al., 1997a; Shaheen et al., 2010).

\section{Monitoring of Biofilms}

Detection, monitoring and control of biofilms in the dairy industry are vital to controlling spoilage of heat-treated products and, in the context of pathogenic microbes, ensuring consumer safety. To be able to minimize contamination and build-up of biofilms within equipment, adequate, and timely monitoring is of the essence. Biofilm detection and monitoring have, over the years, been performed using culture-dependent as well as cultureindependent online methods. While a myriad of approaches are available, it has been highlighted that some of the methods developed in the laboratory to detect and monitor biofilms 
cannot directly be transferred to industrial settings due to their delicate nature or limited practicability (Janknecht and Melo, 2003).

The most common of the biofouling monitoring methods that are used by industry involve indirect testing through assessing process performance, product quality or offline chemical, physical, and biological studies on samples collected from the manufacturing process (Flemming, 2003). However, other approaches exist which rely on qualitative visual inspection of equipment, direct measurement of microbiological characteristics of biofilms, heat transfer and pressure drop measurements across the manufacturing line, measurement of optical signals, measurement of electric signals, or measurement of vibration signals (Pereira et al., 2009). Biofilm detection has also been attempted by researchers and clinicians using a variety of molecular methods. These, and other, techniques are not discussed in detail in this review and readers are referred to several other reviews that specifically address the topic of biofouling monitoring (Flemming, 2003; Janknecht and Melo, 2003; Hasting, 2005; Pereira et al., 2009; Tan et al., 2014). Once accurate detection and monitoring approaches have been established, the next step is then to devise and apply reliable control measures.

\section{Control of Biofilms}

As is apparent from the information provided above, the control and removal of biofilms is essential with respect to preventing the contamination of dairy products. It is also critical with respect to preventing mechanical blockages and failures in equipment. Several approaches can be used to control biofilms in the dairy industry and the most common ones are as follows: alteration of the surface chemistry to prevent cell attachment, treatment of surfaces with antimicrobial agents, optimization of the process and equipment design or the use of intensive cleaning regimens (Bower et al., 1996). In the latter case, cleaning-inplace (CIP) processes are particularly important. These involve the washing out of milk processing lines with cleaning and sanitizing chemicals, with additional antimicrobial substances for an enhanced performance. Although CIP has proven to be a valuable strategy since its introduction in the 1950s (Bremer et al., 2009), there have been efforts to develop new strategies based on increased understanding of bacterial genetics, systems biology, materials and mechanic engineering and chemical biology (Tan et al., 2014). Other strategies to control biofilms in the dairy industry have also been proposed. These include the so-called green strategy for biofilm control, namely enzymebased detergents, control using bacteriophages and control through microbial interactions or metabolite molecules (Simões et al., 2010); disinfection and removal of biofilm layers using ozone $\left(\mathrm{O}_{3}\right)$ water and hydrogen peroxide solution (Tachikawa and Yamanaka, 2014); ultrasound treatments coupled with heat and/or pressure (Piyasena et al., 2003); high-intensity focused ultrasound (Xu et al., 2012); via the usage of biotherapeutic agents such as lactoferrin (Ammons and Copié, 2014) and via the usage of a variety of antimicrobials such as nisin, lauricidin or reuterin (Dufour et al., 2004; El-Ziney and Jakobsen, 2009). Some of these approaches are described in greater depth below, and a summary of the benefits and limitations of the various approaches can also be found in Table 1.

\section{Cleaning-in-Place Processes}

Cleaning-in-place protocols vary according to industries and the residues that need to be cleaned. Within dairy manufacturing plants, deposits can either be organic such as fats, un-denatured and denatured proteins, sugar, minerals, fruit cells and secondary manufacturing products such as gums, starches, emulsifiers and stabilizers, or inorganic such as calcium phosphate (Walton, 2008). As some processed dairy products have lower nutrient concentrations and water activity as compared to raw milk, spore-formation is favored over growth of vegetative cells, enhancing the need for different cleaning regimes in processing plants. While the cleaning process involves a combination of aqueous, foam or gel acidic and alkaline detergents, disinfection is carried out via a range of biocides that are able to reduce live bacterial cells and their subsequent outgrowth on surfaces such that they do not affect the specification of products. In the dairy industry, alkaline/caustic detergents (e.g., sodium hydroxide) are effective against organic deposits such as milk proteins and fat and work best at a temperature of $60-73^{\circ} \mathrm{C}$ whilst acidic solutions (nitric acid) removes mineral deposits (e.g., calcium phosphate) from milk and water (Chisti, 1999; Keown and Kononoff, 2006; Bava et al., 2011). Nowadays, caustic blends containing additives, surfactants, emulsifying agents, chelating compounds and complexing agents and acid blends containing other acids and surfactants are being used for enhanced cleaning regimens and safer end products (Bremer et al., 2006).

\section{Biocides}

Even though optimized CIP processes are the standard cleaning procedures globally across dairy industries, the process mainly focuses on cleaning residues from equipment surfaces and reducing viable bacterial counts rather than removing established biofilms and reducing biofilm development (Parkar et al., 2003). As none of the current control strategies are able to remove biofilms completely, better and more effective biocides that are in line with the EC directive regarding biocidal products [Regulation (EU) No 528/2012], combined control processes and alternative control methods need to be implemented, while at the same time keeping in mind costs, labor, energy usage, and product safety (Simões et al., 2010).

Across the dairy industry, the use of chemical biocides is routine with the choice of biocide reflecting some important considerations, including the need to be environmentally friendly, economical, non-toxic, non-allergenic, should not react with the surface material (corrosion or staining), is stable over ranges of $\mathrm{pH}$ and temperatures and should have a broad activity spectrum (Møretrø et al., 2012). The most common chemical disinfectants include oxidizing agents and chlorinebased detergents (sodium hypochlorite), hydrogen peroxide, ozone and peracetic acid, surface active compounds including quaternary ammonium compounds (QACs) and acid anionic compounds and iodophores (Van Houdt and Michiels, 2010). Disinfection alone is not enough to eliminate biofilms as they leave the EPS matrix intact (Pontefract, 1991). Therefore, it 
TABLE 1 | Benefits and limitations of approaches used to control and remove biofilms prevalent in the dairy industry.

\begin{tabular}{|c|c|c|c|c|}
\hline Control strategies & Examples of approach & Pros & Cons & Reference \\
\hline
\end{tabular}

\section{Physical approach}

(1) Cleaning-in-place processes (CIP)
Via a combination of acidic (e.g., nitric acid) and alkaline (e.g., sodium hydroxide) detergents
- Highly efficient if specifically optimized • High water consumption treated

- Multi-functional systems are efficient and economic

- Efficiency of regimes can be increased by altering conditions such as temperature and concentration of detergents

(1a) Chemically enhanced CIP

(1b) Biologically enhanced CIP

(2) Ultrasonication
Specific CIP with the addition of • Chemicals increase effectiveness of surfactants, chelating compounds, emulsifying agents, or complexing agents cleaning process

- Provide bacteriostatic conditions to delay further growth of microorganisms

Specific CIP with the addition of • Reduced usage of potentially enzymes

hazardous chemicals as per the fouled deposits being
- More environmentally friendly than using chemicals

- Reduced energy consumption as enzymes can operate at low temperatures

- Enzymatic cleaning reduces chemical and thermal stress on cleaning equipment

Low frequency/high intensity ultrasound ( $\geq 20 \mathrm{kHz}$ )
- Easily de-agglomerates bacterial clusters by acoustic cavitation

- No loss of nutrients and flavors as ultrasonication is non-thermal
- High energy usage to operate equipment

- Single-use CIP units are expensive to operate

- Process is time-consuming and any cleaning time is classified as downtime

- Chemicals are non-biodegradable and not environmentally friendly

- Increased costs

- Requires post-cleaning neutralization

- Commercial enzymatic preparations are expensive

- Enzymatic activity can be reduced by the presence of in situ inhibitors
Palabiyik et al., 2015

Tamime, 2008

White and Rabe, 1970

Paul et al., 2014
- Technique is expensive due to high intensities required

- Not efficient enough on its own and requires combining with other treatment techniques such as enzymes or biocides

\section{Biological approach}

(1) Biological biocides

Enzymes (e.g., proteases and polysaccharide-hydrolysing enzymes) and bacteriocins (e.g., nisin, lacticin 3147, or pediocin PA1)

(2) Bacteriophages
Act via a lytic or lysogenic pathway to infect bacteria
- Environmentally friendly

- Bacteriocins deriving from lactic acid bacteria have GRAS status (generally recognized as safe)

- Wide antibacterial spectrum

- Bacteriocins are not active and non-toxic to eukaryotic cells

- Bacteriocins do not affect the gut microbiota

- Highly specific to target pathogenic bacteria

- Self-limiting

- Self-dosing

- Rapid isolation

- Less costly than antibiotics
- Enzymes are highly specific and setting up a cocktail of enzyme against biofilms is time-consuming and expensive

- Bacteria in biofilms have developed resistance to biocides

- Bacteriocins do not always target the desired bacterial group

- A complex food microbiota can reduce the efficacy of bacteriocins

- Phage-resistance mechanisms are evolving

- Some phages carry antibiotic-resistance genes and other virulence factors

- Phages are perceived as intruders by the immune system (immunogenicity), which affect in vivo efficacy

- Ethical and social concerns towards genetic manipulation
Chemical approach

(1) Chemical biocides
Oxidizing agents (e.g., hydrogen peroxide), chlorine-based detergents (e.g., sodium hypochlorite), surface active compounds (e.g., quaternary ammonium compounds), iodophores

Via either molecular ozone or its • Environmentally friendly decomposition products (e.g., • Has GRAS status hydroxyl radicals) biological biocides and applied
- Chemical biocides work at a range of - Not environmentally friendly $\mathrm{pH}$, temperature, and concentrations

- More cost-efficient as compared to

- Chemical mixes are easily prepared

- Rapid inactivation and leaves no residual components

- Low overall energy consumption
- Chlorine-based detergents are instable and toxic

- Some chemicals have corrosive effects on surfaces

- Hydrogen peroxide is effective only at high concentrations

- Efficacy is highly dependent on temperature and $\mathrm{pH}$ as well as target microorganism

- Can cause irritation and other symptoms even at low concentrations
Joyce et al., 2003 Cameron et al., 2008 Srey et al., 2013

Cleveland et al., 2001; Sobrino-López and Martín-Belloso, 2008 Gálvez et al., 2007

Kutter et al., 2010; Nobrega et al., 2015
Graham, 1997;

Khadre et al., 2001;
Cullen and Norton, 2012

Van Houdt and Michiels, 2010

Vlková et al., 2008 
has been suggested that chemical control of biofilms should be coupled with mechanical methods to disrupt and break down the matrix, hereby reducing bacterial adherence to surfaces and increasing the effects of chemical biocides (Kumar and Anand, 1998).

More recently, biological biocides such as enzymes and bacteriocins have gradually been introduced in an attempt to change the physico-chemical properties of adhesion surfaces as well as to provide a 'greener' and more environmentally friendly control method. Enzymes, which are non-toxic and highly specific, have been used by several research groups as an alternative method of control of biofilms. The efficiency of these enzymes is dependent on the species of bacteria involved and, as the EPS matrix is heterogeneous in nature, a combination of enzymes is usually required (Simões et al., 2010). When combined with surfactants to improve cleaning efficacy, proteases (e.g., savinase, everlase, polarzyme) and polysaccharide-hydrolysing enzymes (e.g., amylase, cellulase, pectinesterase, pectin lyase) have proven effective in the degradation of the EPS matrix and removal of bacterial biofilms (Parkar et al., 2004; Molobela et al., 2010; Srey et al., 2013). Meanwhile, bacteriocins, which are "ribosomally synthesized antimicrobial peptides produced by one bacterium that are active against bacteria, either in the same species (narrow spectrum) or across genera (broad spectrum)" (Cotter et al., 2005) have also been trialed in the control of biofilms (Bowdish et al., 2005). The LAB-derived bacteriocins that could potentially be employed by the dairy industry for this purpose include nisin, lacticin 3147 or 481, and pediocin PA-1 (Deegan et al., 2006). Notably, nisin is already widely used across the food industry and is categorized as a generally recognized as safe (GRAS) compound. These bio-active compounds can be adsorbed onto surfaces and are able to inhibit the adhesion of bacterial cells. There are thus a range of chemical and biological biocides which are relatively effective against biofilms. However, the development of resistance to some of the compounds already in use means that the more rapid commercialisation of solutions that to date have only been applied at a laboratory scale, is essential.

\section{Other Methods}

While CIP processes and biocides have been key components of conventional cleaning approaches in dairy manufacturing plants, the aforementioned acquisition of resistance by bacteria is a cause for concern. Therefore, novel and improved control approaches must be introduced to maintain the quality and safety of dairy products. A summary of a few emerging control strategies will be presented in this review and readers are directed to reviews dedicated to novel and emerging methods of biofilm control for a comprehensive insight into the subject (Simões et al., 2010; Teixeira and Rodrigues, 2014).

\section{Ozone}

Ozone, a highly oxidizing gas, is a potent antimicrobial used to combat bacteria, fungi, viruses, protozoa, and bacterial spores via the disruption of the cell envelope (Khadre et al., 2001; Srey et al., 2013). Khadre et al. (2001) have demonstrated that molecular ozone and its decomposition products, e.g., hydroxyl radicals, react with intracellular enzymes, nucleic materials and components of the cell envelope and spore coats to inactivate bacteria and, hence, disintegrate biofilms. However, despite having strong antimicrobial properties, ozone is unstable and quickly degenerates into its by-products, water and oxygen, before it can act on microorganisms (Teixeira and Rodrigues, 2014).

\section{Ultrasonication}

Ultrasonication is "a non-thermal process that uses sound waves with frequencies greater than the limit for human hearing, i.e., $20 \mathrm{kHz}$ or higher" to inactivate pasteurization-resistant microorganisms (Khanal et al., 2014a). Inactivation of bacteria is done via low frequency ultrasound (also called high intensity or power ultrasound) applied in a liquid medium, whereby power levels of $10-1000 \mathrm{~W} / \mathrm{cm}^{2}$ are generated resulting in cavitation (Raso et al., 1998; Villamiel et al., 2009). One of the latest studies on ultrasonication applied to thermoduric aerobic sporeformers has determined that high intensity power ultrasonication is able to inactivate microorganisms within $10 \mathrm{~min}$ and, when combined with pasteurization, all vegetative microbial cells are inactivated (Khanal et al., 2014b). The same research group has also been investigating the actions of ultrasonication on spores of B. coagulans, B.licheniformis, and G. stearothermophilus. Their studies determined that high intensity ultrasonication combined with pasteurization inactivated $65.74 \%$ of endospores present in non-fat milk while ultrasonication combined with a heat treatment at $80^{\circ} \mathrm{C}$ for $1 \mathrm{~min}$ inactivated $75.32 \%$ of endospores (Khanal et al., 2014b). Despite being a powerful tool as it can reach biofilms in cracks and crevices, ultrasonication alone cannot completely dislodge all biofilms. As noted above, perhaps through its use in combination with other antimicrobial agents (also including EDTA or ozonation), it can prove to be efficient (Baumann et al., 2009; Teixeira and Rodrigues, 2014).

\section{Bacteriophage}

Bacteriophage or 'phage' are ubiquitous "viruses that infect bacteria and are found in the same biosphere niches as their bacterial hosts" (Kutter and Sulakvelidze, 2005). Phage are able to control microbial biofilms in a natural, non-toxic and highly specific manner while being dependent on chemical composition and factors such as temperature, growth stage, media, and phage concentration (Sillankorva et al., 2004; Chaignon et al., 2007). Phage can be used against single-species but also against multispecies biofilms as they are able to target their specific host without binding to co-resident species (Sillankorva et al., 2010). It has been suggested that phage and bacteria can gradually come to co-exist in biofilms and, thus, combining phages with polysaccharide depolymerases or disinfectants may be vital for successful applications (Tait et al., 2002). It is important to note, however, that although phage therapy is considered to have considerable potential for such applications, several limitations still hinder its widespread usage as a reliable approach. These drawbacks include (i) the acquisition of resistance by mutated bacteria via mechanisms such as the blockage of phage adsorption, (ii) the prevalence of antibiotic-resistant genes or bacterial virulence factors in the phages that can be transduced to 
bacteria, (iii) questions regarding immunogenicity and effective in vivo usage of phages (iv) ethical and social concerns from the public in relation to genetic manipulation, and (v) appropriate classification and regulation of native phages due to their unconventionality (Gill and Hyman, 2010; Hyman and Abedon, 2010; Kutter et al., 2010; Drulis-Kawa et al., 2012; Vandamme and Miedzybrodzki, 2013; Nobrega et al., 2015).

\section{CONCLUSION}

Profitability and reputation in the dairy industry are highly dependent on the quality and safety of the products generated. Pasteurization and refrigeration are the most important processes employed by industry to control pathogens and spoilagecausing microorganisms, but, their success can be restricted due to the existence of several bacterial species that are able to survive the industrial pasteurization process. Aerobic sporeforming bacteria, which form resistant biofilms, are able to survive these harsh conditions and result in dairy manufacturing plants suffering economic losses and shorter run times for equipment. Presenting a significant challenge for the dairy industry as well as the food/beverages industry as a whole, a

\section{REFERENCES}

Adams, D. M., Barach, J. T., and Speck, M. L. (1975). Heat resistant proteases produced in milk by psychrotrophic bacteria of dairy origin. J. Dairy Sci. 58, 828-834. doi: 10.3168/jds.S0022-0302(75)84645-5

Agata, N., Ohta, M., Mori, M., and Isobe, M. (1995). A novel dodecadepsipeptide, cereulide, is an emetic toxin of Bacillus cereus. FEMS Microbiol. Lett. 129, 17-20. doi: 10.1016/0378-1097(95)00119-p

Ahn, J.-H., Kim, B., Kim, B.-Y., Kim, S.-J., Song, J., Kwon, S.-W., et al. (2014). Paenibacillus cucumis sp. nov. isolated from greenhouse soil. J. Microbiol. 52, 460-464. doi: 10.1007/s12275-014-4071-7

Ammons, M. C., and Copié, V. (2014). Mini-review: Lactoferrin: a bioinspired, anti-biofilm therapeutic. Biofouling 29, 443-455. doi: 10.1080/08927014.2013.773317

An, S.-Y., Haga, T., Kasai, H., Goto, K., and Yokota, A. (2007). Sporosarcina saromensis sp. nov., an aerobic endospore-forming bacterium. Int. J. Syst. Evol. Microbiol. 57, 1868-1871. doi: 10.1099/ijs.0.64962-0

Andersson, A., Granum, P. E., and Rönner, U. (1998). The adhesion of Bacillus cereus spores to epithelial cells might be an additional virulence mechanism. Int. J. Food Microbiol. 39, 93-99. doi: 10.1016/S0168-1605(97)00121-9

Andrews, A. T. (1991). "Indigenous enzymes in milk," in Food Enzymology, ed. P. F. Fox (New York, NY: Elsevier Science Publishers), 54-61.

Anonymous (1997). Bacillus cereus Determination in Foods. NKML Method No. 67, 4th Edn. Oslo: The Nordic Committee on Food Analysis.

Ash, C., Farrow, J., Wallbanks, S., and Collins, M. (1991). Phylogenetic heterogeneity of the genus Bacillus revealed by comparative analysis of smallsubunit-ribosomal RNA sequences. Lett. Appl. Microbiol. 13, 202-206. doi: 10.1111/j.1472-765X.1991.tb00608.x

Ash, C., Priest, F. G., and Collins, M. D. (1993). Molecular identification of rRNA group 3 bacilli (Ash, Farrow, Wallbanks and Collins) using a PCR probe test. Proposal for the creation of a new genus Paenibacillus. Antonie Van Leeuwenhoek 64, 253-260. doi: 10.1007/BF00873085

Banat, I. M., Marchant, R., and Rahman, T. J. (2004). Geobacillus debilis sp. nov., a novel obligately thermophilic bacterium isolated from a cool soil environment, and reassignment of Bacillus pallidus to Geobacillus pallidus comb. nov. Int. J. Syst. Evol. Microbiol. 54, 2197-2201. doi: 10.1099/ijs.0.63231-0

Baumann, A. R., Martin, S. E., and Feng, H. (2009). Removal of Listeria monocytogenes biofilms from stainless steel by use of ultrasound and ozone. J. Food Protect. 72, 1306-1309. greater understanding of the composition of biofilms and the factors that lead to their development is vital. Comprehensive research into the development of physical, chemical, and biological control strategies will eventually lead to new and innovative approaches to control biofilms. Meanwhile, whilst the novel approaches to controlling biofilms are still being evaluated, CIP approaches enhanced by chemical or biological biocides remain the most reliable cleaning strategies in the dairy industry.

\section{AUTHOR CONTRIBUTIONS}

NG - MSc student. CH and PC - Supervisor and co-supervisor. $\mathrm{PR}, \mathrm{TB}$, and MF - Scientific contributors and involved in setting up grant and fundings.

\section{ACKNOWLEDGMENT}

NG is funded by the Teagasc Walsh Fellowship Scheme and through the Irish Dairy Levy funded project 'ThermodurOut.'

Bava, L., Zucali, M., Sandrucci, A., Brasca, M., Vanoni, L., Zanini, L., et al. (2011). Effect of cleaning procedure and hygienic condition of milking equipment on bacterial count of bulk tank milk. J. Dairy Res. 78, 211-219. doi: 10.1017/S002202991100001X

Beattie, S., and Williams, A. (1999). Detection of toxigenic strains of Bacillus cereus and other Bacillus spp. with an improved cytotoxicity assay. Lett. Appl. Microbiol. 28, 221-225. doi: 10.1046/j.1365-2672.1999.0 0498.x

Beecher, D. J., Schoeni, J. L., and Wong, A. C. (1995). Enterotoxic activity of hemolysin BL from Bacillus cereus. Infect. Immun. 63, 4423-4428.

Benno, Y., Sawada, K., and Mitsuoka, T. (1984). The intestinal microflora of infants; composition of fecal flora in breast and bottle fed infants. Pediatr. Infect. Dis. J. 4:308.

Blowey, R. W., and Edmondson, P. (2010). "Bactoscan and total bacterial count chap. 10," in Mastitis Control in Dairy Herds, ed. S. Hulbert, 2nd Edn. Oxfordshire: CAB International.

Bowdish, D. M., Davidson, D. J., and Hancock, R. E. (2005). A re-evaluation of the role of host defence peptides in mammalian immunity. Curr. Protein Pept. Sci. 6, 35-51. doi: 10.2174/1389203053027494

Bower, C., McGuire, J., and Daeschel, M. (1996). The adhesion and detachment of bacteria and spores on food-contact surfaces. Trends Food Sci. Technol. 7, 152-157. doi: 10.1016/0924-2244(96)81255-6

Bremer, P. J., Fillery, S., and McQuillan, A. J. (2006). Laboratory scale Clean-InPlace (CIP) studies on the effectiveness of different caustic and acid wash steps on the removal of dairy biofilms. Int. J. Food Microbiol. 106, 254-262. doi: 10.1016/j.ijfoodmicro.2005.07.004

Bremer, P. J., Seale, B., Flint, S., Palmer, J., Fratamico, P., Annous, B., et al. (2009). "Biofilms in dairy processing," in Biofilms in the Food and Beverage Industries, eds P. M. Fratamico, B. A. Annous and N. W. Guenther (Amsterdam: Elsevier), 96-431.

Buehner, K. P., Anand, S., and Garcia, A. (2014). Prevalence of thermoduric bacteria and spores on 10 Midwest dairy farms. J. Dairy Sci. 97, 6777-6784. doi: 10.3168/jds.2014-8342

Burgess, S. A., Flint, S. H., and Lindsay, D. (2013). Characterization of thermophilic bacilli from a milk powder processing plant. J. Appl. Microbiol. 116, 350-359. doi: $10.1111 /$ jam.12366

Burgess, S. A., Lindsay, D., and Flint, S. H. (2010). Thermophilic bacilli and their importance in dairy processing. Int. J. Food Microbiol. 144, 215-225. doi: 10.1016/j.ijfoodmicro.2010.09.027 
Caamaño-Antelo, S., Fernández-No, I., Böhme, K., Ezzat-Alnakip, M., QuintelaBaluja, M., Barros-Velázquez, J., et al. (2015). Genetic discrimination of foodborne pathogenic and spoilage Bacillus spp. based on three housekeeping genes. Food Microbiol. 46, 288-298. doi: 10.1016/j.fm.2014.08.013

Cameron, M., McMaster, L. D., and Britz, T. J. (2008). Electron microscopic analysis of dairy microbes inactivate by ultrasound. Ultrason Biochem. 15, 960-964. doi: 10.1016/j.ultsonch.2008.02.012

Chaignon, P., Sadovskaya, I., Ragunah, C., Ramasubbu, N., Kaplan, J. B., and Jabbouri, S. (2007). Susceptibility of staphylococcal biofilms to enzymatic treatments depends on their chemical composition. Appl. Microbiol. Biotechnol. 75, 125-132. doi: 10.1007/s00253-006-0790-y

Chapela, M., Garrido-Maestu, A., Cabado, A., and Yildiz, F. (2015). Detection of foodborne pathogens by qPCR: a practical approach for food industry applications. Cogent Food Agric. 1. doi: 10.1080/23311932.2015.1013771

Chen, L., Coolbear, T., and Daniel, R. M. (2004). Characteristics of proteinases and lipases produced by seven Bacillus sp. isolated from milk powder production lines. Int. Dairy J. 14, 495-504. doi: 10.1016/j.idairyj.2003.10.006

Chen, L., Daniel, R. M., and Coolbear, T. (2003). Detection and impact of protease and lipase activities in milk and milk powders. Int. Dairy J. 13, 255-275. doi: 10.1016/S0958-6946(02)00171-1

Chisti, Y. (1999). "Modern systems of plant cleaning," in Encyclopedia of Food Microbiol, eds R. Robinson, C. Batt, and P. Patel (London: Academic press), 1806-1815. doi: 10.1006/rwfm.1999.3020

Chmielewski, R., and Frank, J. (2003). Biofilm formation and control in food processing facilities. Comp. Rev. Food Sci. Food Soc. 2, 22-32. doi: 10.1111/j.1541-4337.2003.tb00012.x

Christiansson, A., Bertilsson, J., and Svensson, B. (1999). Bacillus cereus spores in raw milk: factors affecting the contamination of milk during the grazing period. J. Dairy Sci. 82, 305-314. doi: 10.3168/jds.S0022-0302(99)75237-9

Clark, S., Jung, S., and Lamsal, B., (eds). (2014). Food Processing: Principles and Applications, 2nd Edn. Hoboken, NJ: John Wiley \& Sons.

Claus, D., and Berkeley, R. C. W. (1986). "Genus Bacillus cohn 1872, 174 AL”, in Bergey's Manual of Systematic Bacteriology, Vol. 2, eds G. G. Boone, R. David, and R. W. Castenholz (Baltimore: Williams \& Wilkins), 1105-1139.

Clavel, T., Carlin, F., Lairon, D., and Schmitt, P. (2004). Survival of Bacillus cereus spores and vegetative cells in acid media simulating human stomach. J. Appl. Microbiol. 97, 214-219. doi: 10.1111/j.1365-2672.2004.02292.x

Cleveland, J., Montville, T. J., Nes, I. F., and Chikindas, M. L. (2001). Bacteriocins: safe natural antimicrobials for food preservation. Int. J. Food Microbiol. 71, 1-20. doi: 10.1016/S0168-1605(01)00560-8

Codex Alimentarius Commission (2007). Standard for infant formula and formulas for special medical purposes intended for infants. CODEX STAN 72.

Collins, E. B. (1981). Heat resistant psychrotrophic microorganisms. J. Dairy Sci. 64, 157-160. doi: 10.3168/jds.S0022-0302(81)82543-X

Coorevits, A., De Jonghe, V., Vandroemme, J., Van Landschoot, A., Heyndrickx, M., and De Vos, P. (2010). "How can the type of dairy farming influence the bacterial flora in milk?," in Organic Farming and Peanut Crops, eds A. Coorevits, V. De Jonghe, J. Vandroemme, A. Van Landschoot, M. Heyndrickx, and P. De Vos (Ghent: NOVA Science Publishers), 123-136.

Cotter, P. D., Hill, C., and Ross, R. P. (2005). Bacteriocins: developing innate immunity for food. Nat. Rev. Microbiol. 3, 777-788.

Craven, H., and Macauley, B. (1992). Microorganisms in pasteurised milk after refrigerated storage. 1. Identification of types. Aust. J. Dairy Technol. 1, 38-45.

Crielly, E., Logan, N., and Anderton, A. (1994). Studies on the Bacillus flora of milk and milk products. J. Appl. Bacteriol. 77, 256-263. doi: 10.1111/j.13652672.1994.tb03072.x

Cullen, P. J., and Norton, T. (2012). "Ozone sanitisation in the food industry," in Ozone in Food Processing, 1st Edn, eds C. O’Donnell, B. K. Tiwari, P. J. Cullen, and G. Rice (Hoboken, NJ: Blackwell Publishing).

Daane, L., Harjono, I., Barns, S., Launen, L., Palleron, N., and Häggblom, M. (2002). PAH-degradation by Paenibacillus spp. and description of Paenibacillus naphthalenovorans sp. nov., a naphthalene-degrading bacterium from the rhizosphere of salt marsh plants. Int. J. Syst. Evol. Microbiol. 52, 131-139. doi: 10.1099/00207713-52-1-131

Damgaard, P., Larsen, H., Hansen, B., Bresciani, J., and Jørgensen, K. (1996). Enterotoxin-producing strains of Bacillus thuringiensis isolated from food. Lett. Appl. Microbiol. 23, 146-150. doi: 10.1111/j.1472-765X.1996.tb00051.x
Deegan, L. H., Cotter, P. D., Hill, C., and Ross, P. (2006). Bacteriocins: biological tools for bio-preservation and shelf-life extension. Int. Dairy J. 16, 1058-1071. doi: 10.1016/j.idairyj.2005.10.026

Deeth, H. C., and Fitz-Gerald, C. H. (1994). "Lipolytic enzymes and hydrolytic rancidity in milk and milk products," in Advanced Dairy Chemistry, 2nd Edn, Vol. 2, eds P. L. H. McSweeney and P. F. Fox (London: Chapman \& Hall).

De Jonghe, V., Coorevits, A., De Block, J., Van Coillie, E., Grijspeerdt, K., Herman, L., et al. (2010). Toxinogenic and spoilage potential of aerobic sporeformers isolated from raw milk. Int. J. Food Microbiol. 136, 318-325. doi: 10.1016/j.ijfoodmicro.2009.11.007

Dhakal, R., Chauhan, K., Seale, R. B., Deeth, H. C., Pillidge, C. J., Powell, I. B., et al. (2013). Genotyping of dairy Bacillus licheniformis isolates by high resolution melt analysis of multiple variable number tandem repeat loci. Food Microbiol. 34, 344-351. doi: 10.1016/j.fm.2013.01.006

Dhakal, R., Seale, R. B., Deeth, H. C., Craven, H., and Turner, M. S. (2014). Draft genome comparison of representatives of the three dominant genotype groups of dairy Bacillus licheniformis strains. Appl. Environ. Microbiol. 80, 3453-3462. doi: 10.1128/AEM.00065-14

Di Pinto, A., Bonerba, E., Bozzo, G., Ceci, E., Terio, V., and Tantillo, G. (2013). Occurence of potentially enterotoxigenic Bacillus cereus in infant milk powder. Eur. Food Res. Technol. 237, 275-279. doi: 10.1007/s00217-0131988-8

Donlan, R. M. (2002). Biofilms: microbial life on surfaces. Emerg. Infect. Dis. 8, 881-890. doi: 10.3201/eid0809.020063

Doyle, C. J., Gleeson, D., Jordan, K., Beresford, T. P., Ross, R. P., Fitzgerald, G. F., et al. (2015). Anaerobic sporeformers and their significance with respect to milk and dairy products. Int. J. Food Microbiol. 197, 77-87. doi: 10.1016/j.ijfoodmicro.2014.12.022

Drulis-Kawa, Z., Majkowska-Skrobek, G., Maciejewska, B., Delattre, A.-S., and Lavigne, R. (2012). Learning from bacteriophages - advantages and limitations of phage and phage-encoded protein applications. Curr. Protein Peptide Sci. 13, 699-722. doi: 10.2174/138920312804871193

Dufour, M., Simmonds, R. S., and Bremer, P. J. (2004). Development of a laboratory scale Clean-In-Place system to test the effectiveness of "natural" antimicrobials against dairy biofilms. J. Food Protect. 67, 1438-1443.

Durak, M. Z., Fromm, H. I., Huck, J. R., Zadoks, R. N., and Boor, K. J. (2006). Development of molecular typing methods for Bacillus spp. and Paenibacillus spp. isolated from fluid milk products. J. Food Sci. 71, M50-M56. doi: 10.1111/j.1365-2621.2006.tb08907.x

Ehling-Schulz, M., Vukov, N., Schulz, A., Shaheen, R., Andersson, M., Martlbauer, E., et al. (2005). Identification and partial characterization of the nonribosomal peptide synthetase gene responsible for cereulide production in emetic Bacillus cereus. Appl. Environ. Microbiol. 71, 105-113. doi: 10.1128/AEM.71.1.105-113.2005

El-Ziney, M. G., and Jakobsen, M. (2009). Effectiveness of reuterin alone and in combination with nisin or other food contact surfaces sanitizers and cleaners for disinfection of stainless steel surfaces contaminated with Escherichia coli and Listeria innocua. J. Food Agric. Environ. 7, 145-149.

European Commission (1991). Directive of 14 May 1991 on infant formulae and follow-on formulae. Food and Drug Administration, O.J. No. L 75, 35.

European Commission (2014). Development of the Dairy Market Situation and the Operation of the 'Milk Package' Provisions. Report from the Commission to the European Parliament and the Council, Brussels. Available at: http://ec.europa.eu/agriculture/milk/milk-package/index_en.htm

European Food Safety Authority (2005). Opinion of the scientific panel on biological hazards on Bacillus cereus and other Bacillus spp. Foodstuffs 175, $1-48$.

Flemming, H. (2003). Role and levels of real-time monitoring for successful anti-fouling strategies - an overview. Water Sci. Technol. 47, 1-8.

Flint, S. (1998). Formation and Control of Biofilms of Thermo-Resistant Streptococci on Stainless Steel, thesis Department of Food Technology, Massey University, Palmerston North.

Flint, S., Bremer, P., and Brooks, J. (1997a). Biofilms in dairy manufacturing plantdescription, current concerns and methods of control. Biofouling 11,81-97. doi: 10.1080/08927019709378321

Flint, S., Brooks, J., and Bremer, P. (1997b). “The influence of cell surface properties of thermophilic streptococci on attachment to stainless steel. J. Appl. Microbiol. 83, 508-517. doi: 10.1046/j.1365-2672.1997.00264.x 
Flint, S., Walker, K., Waters, B., and Crawford. (2007). Description and validation of a rapid $(1 \mathrm{~h})$ flow cytometry test for enumerating thermophilic bacteria in milk powders. J. Appl. Microbiol. 102, 909-915.

Forsythe, S. J. (2005). Enterobacter sakazakii and other bacteria in powdered infant milk formula. Matern Child Nutr. 1, 44-50. doi: 10.1111/j.17408709.2004.00008.x

Fox, P. F., and McSweeney, P. L. (2004). "Cheese: an overview," in Cheese: Chemistry, Physics and Microbiology, General Aspects, 3rd Edn, Vol. 1, eds P. F. Fox, L. H. Paul, T. M. C. McSweeney, and T. P. Guinee (London: Elsevier Academic Press), 1-18.

Fox, P. F, McSweeney P. L. H., Cogan T. M., and Guinee T. P. (eds) (2004). Cheese: Chemistry, Physics and Microbiology: General Aspects, 3rd Edn, Vol. 1 (London: Elsevier Academic Press).

From, C., Hormazábal, V., and Granum, P. E. (2007). Food poisoning associated with pumilacidin-producing Bacillus pumilus in rice. Int. J. Food Microbiol. 115, 319-324. doi: 10.1016/j.ijfoodmicro.2006.11.005

From, C., Pukall, R., Schumann, P., Hormazábal, V., and Granum, P. E. (2005). Toxin-producing ability among Bacillus spp. outside the Bacillus cereus group. Appl. Environ. Microbiol. 71, 1178-1183. doi: 10.1128/AEM.71.3.11781183.2005

Fromm, H. I., and Boor, K. (2004). Characterization of pasteurized fluid milk shelf-life attributes. J. Food Sci. 69, M207-M214. doi: 10.1111/j.13652621.2004.tb09889.x

Galperin, M. Y. (2013). Genome diversity of spore-forming Firmicutes. Microbiol. Spectr. 1:TBS-0015-2012. doi: 10.1128/microbiolspectrum.TBS-0015-2012

Gálvez, A., Abriouel, H., López, R. L., and Omar, N. B. (2007). Bacteriocinbased strategies for food preservation. Int. J. Food Microbiol. 120, 51-70. doi: 10.1016/j.ijfoodmicro.2007.06.001

Garny, K., Horn, H., and Neu, T. R. (2008). Interaction between biofilm development, structure and detachment in rotating annular reactors. Bioproc. Biosyst. Eng. 31, 619-629. doi: 10.1007/s00449-008-0212-x

Ghelardi, E., Celandroni, F., Salvetti, S., Barsotti, C., Baggiani, A., and Senesi, S. (2002). Identification and characterization of toxigenic Bacillus cereus isolates responsible for two food-poisoning outbreaks. FEMS Microbiol. Lett. 208, 129-134. doi: 10.1111/j.1574-6968.2002.tb11072.x

Gilbert, R. J., and Kramer, J. M. (1984). Bacillus cereus enterotoxins: present status. Biochem. Soc. 12, 198-200. doi: 10.1042/bst0120198

Gilbert, R. J., and Kramer, J. M. (1986). “Bacillus cereus food poisoning," in Proceedings of Symposium Progress in Food Safety, eds D. O. Cliver and B. A. Cochrane (Mysore: Food Research Institute), 85-93.

Gill, J., and Hyman, P. (2010). Phage choice, isolation and preparation for phage therapy. Curr. Pharm. Biotechnol. 11, 2-14. doi: 10.2174/13892011079072 5311

Giraffa, G. (2014). "Overview of the ecology and biodiversity of the LAB," in Lactic Acid Bacteria - Biodiversity and Taxonomy, 1st Edn, eds W. H. Holzapfel and B. J. B. Wood (Chichester: John Wiley \& Sons, Ltd.).

Graham, D. M. (1997). Use of ozone for food processing. Food Technol. Chic. 51, $72-75$.

Granum, P. E., Brynestad, S., O’sullivan, K., and Nissen, H. (1993). Enterotoxin from Bacillus cereus: production and biochemical characterization. Ned. Melk Zui. 47, 63-70.

Granum, P. E., O'Sullivan, K., and Lund, T. (1999). The sequence of the nonhaemolytic enterotoxin operon from Bacillus cereus. FEMS Microbiol. Lett. 177, 225-229. doi: 10.1016/S0378-1097(99)00312-2

Griffiths, M. W. (1992). Bacillus cereus in liquid milk and other milk products. Bull. Int. Dairy Fed. 36-39.

Hall-Stoodley, L., and Stoodley, P. (2005). Biofilm formation and dispersal and the transmission of human pathogens. Trends Microbiol. 13, 7-10. doi: 10.1016/j.tim.2004.11.004

Hammer, P., Lembke, F., Suhren, G., and Heeschen, W. (1995). Characterization of a heat resistant mesophilic Bacillus species affecting quality of UHT-milk: a preliminary report. Kieler Milchwirtsch. Forschungsber. 47, 297-305.

Harmsen, H. J., Wildeboer-Veloo, A. C., Grijpstra, J., Knol, J., Degener, J. E., and Welling, G. W. (2000). Development of 16S rRNA-based probes for the coriobacterium group and the atopobium cluster and their application for enumeration of coriobacteriaceae in human feces from volunteers of different age groups. Appl. Environ. Microbiol. 66, 4523-4527. doi: 10.1128/AEM.66.10.4523-4527.2000
Hasting, A. P. M. (2005). "Improving the monitoring of fouling, cleaning and disinfection in closed process plant," in Handbook of Hygiene Control in the Food Industry, eds H. L. M. Lelieveld, M. A. Mostert, and J. Holah (Cambridge: Woodhead Publishing), 572-587.

Heyndrickx, M., Coorevits, A., Scheldeman, P., Lebbe, L., Schumann, P., Rodriguez-Diaz, M., et al. (2012). Emended descriptions of Bacillus sporothermodurans and Bacillus oleronius with the inclusion of dairy farm isolates of both species. Int. J. Syst. Evol. Microbiol. 62(Pt 2), 307-314. doi: 10.1099/ijs.0.026740-0

Heyndrickx, M., and Scheldeman, P. (2002). "Bacilli associated with spoilage in dairy products and other food," in Applications and Systematics of Bacillus and Relatives, (Hoboken, NJ: Wiley), 64-82. doi: 10.1002/9780470696743.ch6

Hillerton, J. E., and Berry, E. A. (2004). "Quality of the milk supply: european regulations versus practice," in Proceeding of the NMC Annual Meeting, Compton, 207-214

Hinton, A., Trinh, K., Brooks, J., and Manderson, G. (2002). Thermophile survival in milk fouling and on stainless steel during cleaning. Food Bioprod. Process. 80, 299-304. doi: 10.1205/096030802321154817

Holland, R., Liu, S.-Q., Crow, V., Delabre, M.-L., Lubbers, M., Bennett, M., et al. (2005). Esterases of lactic acid bacteria and cheese flavour: milk fat hydrolysis, alcoholysis and esterification. Int. Dairy J. 15, 711-718. doi: 10.1016/j.idairyj.2004.09.012

Hong, H. A., To, E., Fakhry, S., Baccigalupi, L., Ricca, E., and Cutting, S. M. (2009). Defining the natural habitat of Bacillus spore-formers. Res. Microbiol. 160, 375-379. doi: 10.1016/j.resmic.2009.06.006

Hoton, F. M., Fornelos, N., N'guessan, E., Hu, X., Swiecicka, I., Dierick, K., et al. (2009). Family portrait of Bacillus cereus and Bacillus weihenstephanensis cereulide-producing strains. Environ. Microbiol. 1, 177-183. doi: 10.1111/j.1758-2229.2009.00028.x

Huck, J. R., Sonnen, M., and Boor, K. J. (2008). Tracking heat-resistant, coldthriving fluid milk spoilage bacteria from farm to packaged product. J. Dairy Sci. 91, 1218-1228. doi: 10.3168/jds.2007-0697

Huck, J. R., Woodcock, N. H., Ralyea, R. D., and Boor, K. J. (2007). Molecular subtyping and characterization of psychrotolerant endospore-forming bacteria in two New York State fluid milk processing systems. J. Food Protect. 70, 2354-2364.

Hüsmark, U., and Rönner, U. (1992). The influence of hydrophobic, electrostatic and morphologic properties on the adhesion of Bacillus spores. Biofouling 5, 335-344. doi: 10.1080/08927019209378253

Hyman, P., and Abedon, S. T. (2010). Bacteriophage host range and bacterial resistance. Adv. Appl. Microbiol. 70, 217-248. doi: 10.1016/S00652164(10)70007-1

International Dairy Federation [Idf] (2013). The Economic Important of Dairying. Brussels: IDF Factsheet Publisher.

Iversen, C., and Forsythe, S. (2003). Risk profile of Enterobacter sakazakii, an emergent pathogen associated with infant milk formula. Trends Food Sci. Technol. 14, 443-454. doi: 10.1016/S0924-2244(03)00155-9

Ivy, R. A., Ranieri, M. L., Martin, N. H., den Bakker, H. C., Xavier, B. M., Wiedmann, M., et al. (2012). Identification and characterization of psychrotolerant sporeformers associated with fluid milk production and processing. Appl. Environ. Microbiol. 78, 1853-1864. doi: 10.1128/AEM. 06536-11

Jackson, S., Goodbrand, R., Ahmed, R., and Kasatiya, S. (1995). Bacillus cereus and Bacillus thuringiensis isolated in a gastroenteritis outbreak investigation. Lett. Appl. Microbiol. 21, 103-105. doi: 10.1111/j.1472-765X.1995.tb0 1017.x

Janknecht, P., and Melo, L. F. (2003). Online biofilm monitoring. Rev. Environ. Sci. Biotechnol. 2, 269-283. doi: 10.1023/B:RESB.0000040461.69 339.04

Joyce, E., Phull, S. S., Lorimer, J. P., and Mason, T. J. (2003). The development and evaluation of ultrasound for the treatment of bacterial suspensions. A study of frequency, power and sonication time on cultured Bacillus species. Ultrason Sonochem 10, 315-318. doi: 10.1016/S1350-4177(03)00101-9

Kalogridou-Vassiliadou, D. (1992). Biochemical activities of Bacillus species isolated from flat sour evaporated milk. J. Dairy Sci. 75, 2681-2686. doi: 10.3168/jds.S0022-0302(92)78030-8

Kämpfer, P., Falsen, E., Lodders, N., and Schumann, P. (2010). Sporosarcina contaminans sp. nov. and Sporosarcina thermotolerans sp. nov., two 
endospore-forming species. Int. J. Syst. Evol. Microbiol. 60, 1353-1357. doi: 10.1099/ijs.0.014423-0

Keown, J. F., and Kononoff, P. J. (2006). Producing Milk with a Low Bacteria Count. (NebGuide: Institute of Agricultural and Natural Resources G), 678.

Khadre, M. A., Yousef, A. E., and Kim, J. G. (2001). Microbiological aspects of ozone applications in food: a review. J. Food Sci. 66, 1242-1252. doi: 10.1016/j.jviromet.2008.06.004

Khanal, S. N., Anand, S., and Muthukumarappan, K. (2014a). Evaluation of highintensity ultrasonication for the inactivation of endospores of 3 bacilli species in nonfat milk. J. Dairy Sci. 97, 5952-5963. doi: 10.3168/jds.2014-7950

Khanal, S. N., Anand, S., Muthukumarappan, K., and Huegli, M. (2014b). Inactivation of thermoduric aerobic sporeformers in milk by ultrasonication. Food control 37, 232-239. doi: 10.1016/j.foodcont.2013.09.022

Kim, B., Bang, J., Kim, H., Kim, Y., Kim, B.-S., Beuchat, L. R., et al. (2014). Bacillus cereus and Bacillus thuringiensis spores in Korean rice: prevalence and toxin production as affected by production area and degree of milling. Food Microbiol. 42, 89-94. doi: 10.1016/j.fm.2014.02.021

Klijn, N., Herman, L., Langeveld, L., Vaerewijck, M., Wagendorp, A. A., Huemer, I., et al. (1997). Genotypical and phenotypical characterization of Bacillus sporothermodurans strains, surviving UHT sterilisation. Int. Dairy J. 7, 421-428. doi: 10.1016/S0958-6946(97)00029-0

Kluyver, A. J., and van Niel, C. B. (1936). Prospects for a natural system of classification of bacteria. Zentralbl. Bakteriol. Parasitenk. Infektionskr. Hyg. Abt. 94, 369-403.

Kramer, J. M., and Gilbert, R. J. (1989). Bacillus cereus and other Bacillus species. Foodborne Bact Pathog. 19, 21-70.

Krishnamurthi, S., Bhattacharya, A., Mayilraj, S., Saha, P., Schumann, P., and Chakrabarti, T. (2009). Description of Paenisporosarcina quisquiliarum gen. nov., sp. nov., and reclassification of Sporosarcina macmurdoensis Reddy et al., 2003 as Paenisporosarcina macmurdoensis comb. nov. Int. J. Syst. Evol. Microbiol. 59(Pt 6), 1364-1370. doi: 10.1099/ijs.0.65130-0

Kuisiene, N., Raugalas, J., and Chitavichius, D. (2004). Geobacillus lituanicus sp. nov. Int. J. Syst. Evol. Microbiol. 54, 1991-1995. doi: 10.1099/ijs.0.02976-0

Kumar, C. G., and Anand, S. (1998). Significance of microbial biofilms in food industry: a review. Int. J. Food Microbiol. 42, 9-27. doi: 10.1016/S01681605(98)00060-9

Kutter, E., De Vos, D., Gvasalia, G., Alavidze, Z., Gogokhia, L., Kuhl, S., et al. (2010). Phage therapy in clinical practice: treatment of human infections. Curr. Pharm. Biotechnol. 11, 69-86. doi: 10.2174/138920110790725401

Kutter, E., and Sulakvelidze, A. (eds). (2005). Introduction, Bacteriophages: Biology, Applications, (Boca Raton, FL: CRC Press).

Kwon, S.-W., Kim, B.-Y., Song, J., Weon, H.-Y., Schumann, P., Tindall, B. J., et al. (2007). Sporosarcina koreensis sp. nov. and Sporosarcina soli sp. nov., isolated from soil in Korea. Int. J. Syst. Evol. Microbiol. 57, 1694-1698. doi: 10.1099/ijs.0.64352-0

Law, J. W. F., Ab Mutalib, N. S., Chan, K. G., and Lee, L. H. (2015). Rapid methods for the detection of foodborne bacterial pathogens: principles, applications, advantages and limitations. Front. Microbiol. 5:770. doi: $10.3389 /$ fmicb. 2014.00770

Ledenbach, L. H., and Marshall, R. T. (2010). "Microbiological spoilage of dairy products," in Compendium of the Microbiological Spoilage of Foods and Beverages, eds W. H. Sperber and M. P. Doyle (New York, NY: Springer), 41-67.

Lemes, A. R. N., Marucci, S. C., Costa, J. R., Alves, E. C., Fernandes, O. A., Lemos, M. V. F., et al. (2015). Selection of B. thuringiensis strains containing genes effective in the control of Spodoptera frugiperda. Bt Res. 6, 1-8.

Lequin, M. H., Vermeulen, J. R., van Elburg, R. M., Barkhof, F., Kornelisse, R. F., Swarte, R., et al. (2005). Bacillus cereus meningoencephalitis in preterm infants: neuroimaging characteristics. Am. J. Neuroradiol. 26, 2137-2143.

Lindsay, D., Mosupye, F., Brözel, V., and Von Holy, A. (2000). Cytotoxicity of alkaline-tolerant dairy-associated Bacillus spp. Lett. Appl. Microbiol. 30, 364-369. doi: 10.1046/j.1472-765x.2000.00732.x

Logan, N. A. (2012). Bacillus and relatives in foodborne illness. J. Appl. Microbiol. 112, 417-429. doi: 10.1111/j.1365-2672.2011.05204.x

Logan, N. A., and De Vos, P. (2009). "Genus IV. Brevibacillus shida, takagi, kadowaki and komagata 1996a, 942VP," in Bergey's Manual of Systematic Bacteriology, Vol. 6, eds G. Garrity, D. R. Boone, and R. W. Castenholz (New York, NY: Springer-Verlag), 304-316.
Logan, N. A., Forsyth, G., Lebbe, L., Goris, J., Heyndrickx, M., Balcaen, A., et al. (2002). Polyphasic identification of Bacillus and Brevibacillus strains from clinical, dairy and industrial specimens and proposal of Brevibacillus invocatus sp. nov. Int. J. Syst. Evol. Microbiol. 52(Pt 3), 953-966. doi: 10.1099/0020771352-3-953

Lücking, G., Stoeckel, M., Atamer, Z., Hinrichs, J., and Ehling-Schulz, M. (2013). Characterization of aerobic spore-forming bacteria associated with industrial dairy processing environments and product spoilage. Int. J. Food Microbiol. 166, 270-279. doi: 10.1016/j.ijfoodmicro.2013.07.004

Lukášová, J., Vyhnálková, J., and Páčová, Z. (2001). Bacillus species in raw milk and in the farm environment. Milchwissenschaft 56, 609-611.

Lund, T., De Buyser, M. L., and Granum, P. E. (2000). A new cytotoxin from Bacillus cereus that may cause necrotic enteritis. Mol. Microbiol. 38, 254-261. doi: 10.1046/j.1365-2958.2000.02147.x

MacBean, R. D. (2009). "Packaging and the shelf life of yogurt," in Food Packaging and Shelf Life: A Practical Guide, ed. G. L. Robertson (Boca Raton, FL: CRC Press), 143.

Mackie, R. I., Sghir, A., and Gaskins, H. R. (1999). Developmental microbial ecology of the neonatal gastrointestinal tract. Am. J. Clin. Nutr. 69, 1035s-1045s.

Magnusson, M., Christiansson, A., and Svensson, B. (2007). Bacillus cereus spores during housing of dairy cows: factors affecting contamination of raw milk. J. Dairy Sci. 90, 2745-2754. doi: 10.3168/jds.2006-754

Maijala, R., Nurmi, E., and Fischer, A. (1995). Influence of processing temperature on the formation of biogenic amines in dry sausages. Meat Sci. 39, 9-22. doi: 10.1016/0309-1740(95)80003-4

Mandal, P. K., Biswas, A. K., Choi, K., and Pal, U. K. (2011). Methods for rapid detection of foodborne pathogens: an overview. Am. J. Food Technol. 6, 87-102. doi: 10.3923/ajft.2011.87.102

Marchant, R., and Banat, I. (2010). "The genus Geobacillus and hydrocarbon utilization," in Handbook of Hydrocarbon and Lipid Microbiology, eds K. N. Timmis, T. J. McGenity, J. R. van der Meer, and V. de Lorenzo (Berlin: Springer), 1887-1896.

Marino, M., Maifreni, M., Moret, S., and Rondinini, G. (2000). The capacity of Enterobacteriaceae species to produce biogenic amines in cheese. Lett. Appl. Microbiol. 31, 169-173. doi: 10.1046/j.1365-2672.2000.00783.x

Marquer, P. (2013). Portrait of the EU Milk Production Sector. Eurostat: Statistics in focus. Available at: http://ec.europa.eu/eurostat/statistics-explained/index.php/Archive:Milk_and_ dairy_production_statistics

McGuire, J., and Kirtley, S. A. (1989). On surface characterization of materials targeted for food contact. J. Food Sci. 54, 224-226. doi: 10.1111/j.13652621.1989.tb08609.x

Mensah, P., Tomkins, A. M., Drasar, B. S., and Harrison, T. J. (1991). Antimicrobial effect of fermented Ghanaian maize dough. J. Appl. Bacteriol. 70, 203-210. doi: 10.1111/j.1365-2672.1991.tb02925.x

Mikkola, R., Andersson, M. A., Grigoriev, P., Teplova, V. V., Saris, N.-E. L., Rainey, F. A., et al. (2004). Bacillus amyloliquefaciens strains isolated from moisturedamaged buildings produced surfactin and a substance toxic to mammalian cells. Arch. Microbiol. 181, 314-323.

Mikkola, R., Andersson, M. A., Teplova, V., Grigoriev, P., Kuehn, T., Loss, S., et al. (2007). Amylosin from Bacillus amyloliquefaciens, a $\mathrm{K}^{+}$and $\mathrm{Na}^{+}$channelforming toxic peptide containing a polyene structure. Toxicon 49, 1158-1171. doi: 10.1016/j.toxicon.2007.02.010

Mikkola, R., Kolari, M., Andersson, M. A., Helin, J., and Salkinoja-Salonen, M. S. (2000). Toxic lactonic lipopeptide from food poisoning isolates of Bacillus licheniformis. Eur. J. Biochem. 267, 4068-4074.

Mikkola, R., Saris, N. E., Grigoriev, P. A., Andersson, M. A., and SalkinojaSalonen, M. S. (1999). Ionophoretic properties and mitochondrial effects of cereulide: the emetic toxin of B. cereus. Eur. J. Biochem. 263, 112-117. doi: 10.1046/j.1432-1327.1999.00476.x

Mistry, V. V. (2001). "Fermented milks and cream," in Applied Dairy Microbiology, 2nd Edn, eds E. H. Marth and J. L. Steele (New York, NY: Marcel Dekker Inc.), 301-326.

Moeller, R., Horneck, G., Rabbow, E., Reitz, G., Meyer, C., Hornemann, U., et al. (2008). Role of DNA protection and repair in resistance of Bacillus subtilis spores to ultrahigh shock pressures simulating hypervelocity impacts. Appl. Environ. Microbiol. 74, 6682-6689. doi: 10.1128/AEM.01091-08 
Molobela, I. P., Cloete, T. E., and Beukes, M. (2010). Protease and amylase enzymes for biofilm removal and degradation of extracellular polymeric substances (EPS) produced by Pseudomonas fluorescens bacteria. Afr. J. Microbiol. Res. 4, 1515-1524.

Moreno Switt, A. I., Andrus, A. D., Ranieri, M. L., Orsi, R. H., Ivy, R., den Bakker, H. C., et al. (2014). Genomic comparison of sporeforming bacilli isolated from milk. BMC Genomics 15:26. doi: 10.1186/1471-2164-15-26

Møretrø, T., Heir, E., Nesse, L. L., Vestby, L. K., and Langsrud, S. (2012). Control of Salmonella in food related environments by chemical disinfection. Food Res. Int. 45, 532-544. doi: 10.1016/j.foodres.2011.02.002

Morgenroth, E. (2003). "Detachment: an often-overlooked phenomenon in biofilm research and modeling," in Biofilms in Wastewater Treatment, eds S. Wuertz, P. A. Wilderer, and P. L. Bishop (London: IWA Publishing), 246-290.

Murphy, P. M., Lynch, D., and Kelly, P. M. (1999). Growth of thermophilic spore forming bacilli in milk during the manufacture of low heat powders. Int. J. Dairy Technol. 52, 45-50. doi: 10.1111/j.1471-0307.1999.tb02069.x

Muytjens, H., Zanen, H., Sonderkamp, H., Kollee, L., Wachsmuth, I. K., and Farmer, J. (1983). Analysis of eight cases of neonatal meningitis and sepsis due to Enterobacter sakazakii. J. Clin. Microbiol. 18, 115-120.

Nazina, T., Tourova, T., Poltaraus, A., Novikova, E., Grigoryan, A., Ivanova, A., et al. (2001). Taxonomic study of aerobic thermophilic bacilli: descriptions of Geobacillus subterraneus gen. nov., sp. nov. and Geobacillus uzenensis sp. nov. from petroleum reservoirs and transfer of Bacillus stearothermophilus, Bacillus thermocatenulatus, Bacillus thermoleovorans, Bacillus kaustophilus, Bacillus thermodenitrificans to Geobacillus as the new combinations G. stearothermophilus, G. th. Int. J. Syst. Evol. Microbiol. 51, 433-446.

Nieminen, T., Rintaluoma, N., Andersson, M., Taimisto, A.-M., Ali-Vehmas, T., Seppälä, A., et al. (2007). Toxinogenic Bacillus pumilus and Bacillus licheniformis from mastitic milk. Vet. Microbiol. 124, 329-339. doi: 10.1016/j.vetmic.2007.05.015

Nobrega, F. L., Costa, A. R., Kluskens, L. D., and Azeredo, J. (2015). Revisiting phage therapy: new applications for old resources. Trends Microbiol. 23, 185191. doi: 10.1016/j.tim.2015.01.006

O'Brien, B., Berry, D. P., Kelly, P., Meaney, W. J., and O'Callaghan, E. J. (2009). A Study of the Somatic Cell Count (SCC) of Irish Milk from Herd Management and Environmental Perspectives. Ph.D. thesis, University College Dublin, Dublin.

O’Sullivan, D. J., Giblin, L., McSweeney, P. L., Sheehan, J. J., and Cotter, P. D. (2013). Nucleic acid-based approaches to investigate microbial-related cheese quality defects. Front. Microbiol. 4:1. doi: 10.3389/fmicb.2013.00001

Paananen, A., Mikkola, R., Sareneva, T., Matikainen, S., Hess, M., Andersson, M., et al. (2002). Inhibition of human natural killer cell activity by cereulide, an emetic toxin from Bacillus cereus. Clin. Exp. Immunol. 129, 420-428. doi: 10.1046/j.1365-2249.2002.01898.x

Palabiyik, I., Yilmaz, M. T., Fryer, P. J., Robbins, P. T., and Toker, O. S. (2015). Minimising the environmental footprint of industrial-scaled cleaning processes by optimisation of a novel clean-in-place system protocol. J. Clean Prod. 108, 1009-1018. doi: 10.1016/j.jclepro.2015.07.114

Pantoja, J. C., Rosa, G. J., Reinemann, D. J., and Ruegg, P. L. (2012). Sampling strategies for total bacterial count of unpasteurized bulk milk. J. Dairy Sci. 95, 2326-2335. doi: 10.3168/jds.2011-5098

Parkar, S., Flint, S., Palmer, J., and Brooks, J. (2001). Factors influencing attachment of thermophilic bacilli to stainless steel. J. Appl. Microbiol. 90, 901-908. doi: 10.1046/j.1365-2672.2001.01323.x

Parkar, S. G., Flint, S. H., and Brooks, J. D. (2003). Physiology of biofilms of thermophilic bacilli - potential consequences for cleaning. J. Ind. Microbiol. Biotechnol. 30, 553-560. doi: 10.1007/s10295-003-0081-x

Parkar, S. G., Flint, S. H., and Brooks, J. D. (2004). Evaluation of the effect of cleaning regimes on biofilms of thermophilic bacilli on stainless steel. J. Appl. Microbiol. 96, 110-116. doi: 10.1046/j.1365-2672.2003.02136.x

Paul, T., Jana, A., Das, A., Mandal, A., Halder, S. K., Mohapatra, P. K. D., et al. (2014). Smart cleaning-in-place process through crude keratinase: an eco-friendly cleaning techniques towards dairy industries. J. Clean Prod. 76, 140-153. doi: 10.1016/j.jclepro.2014.04.028

Pavic, S., Brett, M., Petric, I., Lastre, D., Smoljanovic, M., Atkinson, M., et al. (2005). An outbreak of food poisoning in a kindergarten caused by milk powder containing toxigenic Bacillus subtilis and Bacillus licheniformis. Arch. Lebensmittel. 56, 20-22.
Pereira, A., Melo, L. F., Fratamico, P. M., Annous, B. A., and Gunther, N. W. (2009). "Monitoring of biofilms in the food and beverage industries," in Biofilms in the Food and Beverage Industries, eds A. Pereira and L. F. Melo (Oxford: Wood head Publishing Ltd.), 131-151.

Pettersson, B., Lembke, F., Hammer, P., Stackebrandt, E., and Priest, F. G. (1996). Bacillus sporothermodurans, a new species producing highly heat-resistant endospores. Int. J. Syst. Bacteriol. 46, 759-764. doi: 10.1099/00207713-46-3-759

Phelps, R. J., and McKillip, J. L. (2002). Enterotoxin production in natural isolates of Bacillaceae outside the Bacillus cereus group. Appl. Environ. Microbiol. 68, 3147-3151. doi: 10.1128/AEM.68.6.3147-3151.2002

Phillips, J., and Griffiths, M. (1986). Factors contributing to the seasonal variation of Bacillus spp. in pasteurized dairy products. J. Appl. Bacteriol. 61, 275-285. doi: 10.1111/j.1365-2672.1986.tb04288.x

Phillips, J. D., Griffiths, M. W., Nriagu, J., and Simmons, M. (1990). "Pasteurized dairy products: the constraints imposed by environmental contamination," in Advances in Environmental Science and Technology, eds J. O. Nriagu and M. S. Simmons (New York, NY: John Wiley \& Sons, Inc.), 387-454.

Piyasena, P., Mohareb, E., and McKellar, R. C. (2003). Inactivation of microbes using ultrasound: a review. Int. J. Food Microbiol. 87, 207-216. doi: 10.1016/S0168-1605(03)00075-8

Pontefract, R. (1991). Bacterial adherence: its consequences in food processing. Can. Inst. Food Sci. Technol. J. 24, 113-117. doi: 10.1111/j.1750-3841.2010.01936.x

Postollec, F., Mathot, A.-G., Bernard, M., Divanac'h, M.-L., Pavan, S., and Sohier, D. (2012). Tracking spore-forming bacteria in food: from natural biodiversity to selection by processes. Int. J. Food Microbiol. 158, 1-8. doi: 10.1016/j.ijfoodmicro.2012.03.004

Quigley, L., McCarthy, R., O’Sullivan, O., Beresford, T. P., Fitzgerald, G. F., Ross, R. P., et al. (2013a). The microbial content of raw and pasteurized cow milk as determined by molecular approaches. J. Dairy Sci. 96, 4928-4937. doi: $10.3168 /$ jds.2013-6688

Quigley, L., O’Sullivan, O., Stanton, C., Beresford, T. P., Ross, R. P., Fitzgerad, G. F., et al. (2013b). The complex microbiota of raw milk. FEMS Microbiol. Rev. 37, 664-698. doi: 10.1111/1574-6976.12030

Rainey, F. A., Fritze, D., and Stackebrandt, E. (1994). The phylogenetic diversity of thermophilic members of the genus Bacillus as revealed by $16 \mathrm{~S}$ rDNA analysis. FEMS Microbiol. Lett. 115, 205-211. doi: 10.1111/j.1574-6968.1994.tb06639.x

Rajkovic, A., Uyttendaele, M., Vermeulen, A., Andjelkovic, M., Fitz-James, I., in 't Veld, P., et al. (2008). Heat resistance of Bacillus cereus emetic toxin, cereulide. Lett. Appl. Microbiol. 46, 536-541. doi: 10.1111/j.1472-765X.2008.02350.x

Ranieri, M., and Boor, K. (2009). Short communication: bacterial ecology of high-temperature, short-time pasteurized milk processed in the United States. J. Dairy Sci. 92, 4833-4840. doi: 10.3168/jds.2009-2181

Ranieri, M., and Boor, K. (2010). Tracking and eliminating sporeformers in dairy systems. Aust. J. Dairy Technol. 65, 74-80.

Ranieri, M. L., Ivy, R. A., Mitchell, W. R., Call, E., Masiello, S. N., Wiedmann, M., et al. (2012). Real-time PCR detection of Paenibacillus spp. in raw milk to predict shelf life performance of pasteurized fluid milk products. Appl. Environ. Microbiol. 78, 5855-5863. doi: 10.1128/AEM.01361-12

Raso, J., Palop, A., Pagan, R., and Condon, S. (1998). Inactivation of Bacillus subtilis spores by combining ultrasonic waves under pressure and mild heat treatment. J. Appl. Microbiol. 85, 849-854. doi: 10.1046/j.1365-2672.1998.00593.x

Reddy, G., Matsumoto, G., and Shivaji, S. (2003). Sporosarcina macmurdoensis sp. nov., from a cyanobacterial mat sample from a pond in the McMurdo Dry Valleys, Antarctica. Int. J. Syst. Evol. Microbiol. 53, 1363-1367. doi: 10.1099/ijs.0.02628-0

Reginensi, S. M., Gonzalez, M. J., Olivera, J. A., Sosa, M., Juliano, P., and Bermudez, J. (2011). RAPD-based screening for spore-forming bacterial populations in Uruguayan commercial powdered milk. Int. J. Food Microbiol. 148, 36-41. doi: 10.1016/j.ijfoodmicro.2011.04.020

Roberts, T., and Hitchins, A. (1969). "Resistance of spores," in The Bacterial Spore 1, eds G. W. Gould and A. Hurst (New York, NY: Academic Press), 611-670.

Rönner, U., Husmark, U., and Henriksson, A. (1990). Adhesion of Bacillus spores in relation to hydrophobicity. J. Appl. Bacteriol. 69, 550-556. doi: 10.1111/j.13652672.1990.tb01547.x

Rückert, A., Ronimus, R. S., and Morgan, H. W. (2004). A RAPD-based survey of thermophilic bacilli in milk powders from different countries. Int. J. Food Microbiol. 96, 263-272. doi: 10.1016/j.ijfoodmicro.2004.03.020 
Salkinoja-Salonen, M., Vuorio, R., Andersson, M., Kämpfer, P., Andersson, M., Honkanen-Buzalski, T., et al. (1999). Toxigenic strains of Bacillus licheniformis related to food poisoning. Appl. Environ. Microbiol. 65, 4637-4645.

Sanders, M. E., Morelli, L., and Tompkins, T. A. (2003). Sporeformers as human probiotics: Bacillus, Sporolactobacillus and Brevibacillus. Compr. Rev. Food Sci. Food Saf. 2, 101-110. doi: 10.1111/j.1541-4337.2003.tb00017.x

Scheldeman, P., Goossens, K., Rodriguez-Diaz, M., Pil, A., Goris, J., Herman, L., et al. (2004). Paenibacillus lactis sp. nov., isolated from raw and heattreated milk. Int. J. Syst. Evol. Microbiol. 54, 885-891. doi: 10.1099/ijs.0. 02822-0

Scheldeman, P., Herman, L., Foster, S., and Heyndrickx, M. (2006). Bacillus sporothermodurans and other highly heat-resistant spore formers in milk. J. Appl. Microbiol. 101, 542-555. doi: 10.1111/j.1365-2672.2006.02964.x

Scheldeman, P., Pil, A., Herman, L., De Vos, P., and Heyndrickx, M. (2005). Incidence and diversity of potentially highly heat-resistant spores isolated at dairy farms. Appl. Environ. Microbiol. 71, 1480-1494. doi: 10.1128/AEM.71.3.1480-1494.2005

Schoeni, J. L. (2005). Bacillus cereus food poisoning and its toxins. J. Food Protect. 68, 636-648.

Scott, S. A., Brooks, J. D., Rakonjac, J., Walker, K. M., and Flint, S. H. (2007). The formation of thermophilic spores during the manufacture of whole milk powder. Int. J. Dairy Technol. 60, 109-117. doi: 10.1111/j.14710307.2007.00309.x

Seale, R., Flint, S., McQuillan, A., and Bremer, P. (2008). Recovery of spores from thermophilic dairy bacilli and effects of their surface characteristics on attachment to different surfaces. Appl. Environ. Microbiol. 74, 731-737. doi: 10.1128/AEM.01725-07

Seale, R. B., Dhakal, R., Chauhan, K., Craven, H. M., Deeth, H. C., Pillidge, C. J., et al. (2012). Genotyping of present-day and historical Geobacillus species isolates from milk powders by high-resolution melt analysis of multiple variable-number tandem-repeat loci. Appl. Environ. Microbiol. 78, 7090-7097. doi: 10.1128/AEM.01817-12

Shaheen, R., Svensson, B., Andersson, M. A., Christiansson, A., and SalkinojaSalonen, M. (2010). Persistence strategies of Bacillus cereus spores isolated from dairy silo tanks. Food Microbiol. 27, 347-355. doi: 10.1016/j.fm.2009.11.004

Sheehan, J. D. (2011). "Cheese avoidance of gas blowing," in Encyclopedia of Dairy Science, 2nd Edn, ed. J. W. Fuquay (San Diego, CA: Academic Press) 661-666.

Sheehan, J. D. (2013). Milk quality and cheese diversification. Irish J. Agric. Food Res. 52, 243-253.

Shida, O., Takagi, H., Kadowaki, K., and Komagata, K. (1996). Proposal for two new genera, Brevibacillus gen. nov. and Aneurinibacillus gen. nov. Int. J. Syst. Bacteriol. 46, 939-946. doi: 10.1099/00207713-46-4-939

Shinagawa, K., Konuma, H., Sekita, H., and Sugii, S. (1995). Emesis of rhesus monkeys induced by intragastric administration with the HEp-2 vacuolation factor (cereulide) produced by Bacillus cereus. FEMS Microbiol. Lett. 130, 87-90. doi: 10.1111/j.1574-6968.1995.tb07703.x

Sillankorva, S., Neubauer, P., and Azeredo, J. (2010). Phage control of dual species biofilms of Pseudomonas fluorescens and Staphylococcus lentus. Biofouling 26, 567-575. doi: 10.1080/08927014.2010.494251

Sillankorva, S., Oliveira, R. R., Vieira, M.-J., Sutherland, I., and Azeredo, J. (2004). Bacteriophage $\Phi$ S1 infection of Pseudomonas fluorescens planktonic cells versus biofilms. Biofouling 20, 133-138. doi: 10.1080/08927010410001 723834

Simões, M., Simões, L. C., and Vieira, M. J. (2010). A review of current and emergent biofilm control strategies. LWT-Food Sci. Technol. 43, 573-583. doi: 10.1016/j.lwt.2009.12.008

Slepecky, R. A., and Hemphill, H. E. (2006). The genus Bacillus-nonmedical. Prokaryotes 4, 530-562. doi: 10.1007/0-387-30744-3_16

Sobrino-López, A., and Martín-Belloso, O. (2008). Use of nisin and other bacteriocins for preservation of dairy products. Int. Dairy J. 18, 329-343. doi: 10.1016/j.idairyj.2007.11.009

Somers, J. M., and Kelly, A. L. (2002). Contribution of plasmin to primary proteolysis during ripening of cheese: effect of milk heat treatment and cheese cooking temperature. Le Lait 82, 181-191. doi: 10.1051/lait:2002003

Srey, S., Jahid, I. K., and Ha, S.-D. (2013). Biofilm formation in food industries: a food safety concern. Food Control 31, 572-585. doi: 10.1016/j.foodcont.2012.12.001
Stark, P. L., and Lee, A. (1982). The microbial ecology of the large bowel of breastfed and formula-fed infants during the first year of life. J. Med. Microbiol. 15, 189-203. doi: 10.1099/00222615-15-2-189

Stenfors Arnesen, L., Granum, P. E., Buisson, C., Bohlin, J., and NielsenLeRoux, C. (2011). Using an insect model to assess correlation between temperature and virulence in Bacillus weihenstephanensis and Bacillus cereus. FEMS Microbiol. Lett. 317, 196-202. doi: 10.1111/j.1574-6968.2011.0 2229.x

Stenfors Arnesen, L. P., Fagerlund, A., and Granum, P. E. (2008). From soil to gut: Bacillus cereus and its food poisoning toxins. FEMS Microbiol. Rev. 32, 579-606. doi: 10.1111/j.1574-6976.2008.00112.x

Storgards, E., Simola, H., Sjöberg, A.-M., and Wirtanen, G. (1999a). Hygiene of gasket materials used in food processing equipment part 1: new materials. Food Bioprod. Process 77, 137-145.

Storgards, E., Simola, H., Sjöberg, A.-M., and Wirtanen, G. (1999b). Hygiene of gasket materials used in food processing equipment part 2: aged materials. Food Bioprod. Process 77, 146-155. doi: 10.1205/0960308995 32295

Stratton, J. E., Hutkins, R. W., and Taylor, S. L. (1991). Biogenic amines in cheese and other fermented foods: a review. J. Food Protect. 6, 408-475.

Sung, M., Kim, H., Bae, J., Rhee, S., Jeon, C., Kim, K., et al. (2002). Geobacillus toebii sp. nov., a novel thermophilic bacterium isolated from hay compost. Int. J. Syst. Evol. Microbiol. 52, 2251-2255. doi: 10.1099/00207713-52-6-2251

Suominen, I., Andersson, M. A., Andersson, M. C., Hallaksela, A.-M., Kämpfer, P., Rainey, F. A., et al. (2001). Toxic Bacillus pumilus from indoor air, recycled paper pulp, Norway spruce, food poisoning outbreaks and clinical samples. Syst. Appl. Microbiol. 24, 267-276. doi: 10.1078/0723-2020-00025

Sutherland, A. D., and Murdoch, R. (1994). Seasonal occurrence of psychrotrophic Bacillus species in raw milk, and studies on the interactions with mesophilic Bacillus sp. Int. J. Food Microbiol. 21, 279-292. doi: 10.1016/01681605(94)90058-2

Tachikawa, M., and Yamanaka, K. (2014). Synergistic disinfection and removal of biofilms by a sequential two-step treatment with ozone followed by hydrogen peroxide. Water Res. 64, 94-101. doi: 10.1016/j.watres.2014.06.047

Tait, K., Skillman, L. C., and Sutherland, I. W. (2002). The efficacy of bacteriophage as a method of biofilm eradication. Biofouling 18, 305-311. doi: 10.1111/j.13652672.2008.03743.x

Tamime, A. Y. (2008). "Cleaning-in-Place," in Dairy, Food and Beverages Operations, 3rd Edn, ed. A. Y. Tamime (Oxford: Blackwell Publishing).

Tan, S. Y.-E., Chew, S. C., Tan, S. Y.-Y., Givskov, M., and Yang, L. (2014). Emerging frontiers in detection and control of bacterial biofilms. Curr. Opin. Biotechnol. 26, 1-6. doi: 10.1016/j.copbio.2013.08.002

Tatzel, R., Ludwig, W., Schleifer, K. H., and Wallnfer, P. R. (1994). Identification of Bacillus strains isolated from milk and cream with classical and nucleic acid hybridization methods. J. Dairy Res. 61, 529-535. doi: 10.1017/S0022029900028454

Taylor, J. M., Sutherland, A. D., Aidoo, K. E., and Logan, N. A. (2005). Heatstable toxin production by strains of Bacillus cereus, Bacillus firmus, Bacillus megaterium, Bacillus simplex and Bacillus licheniformis. FEMS Microbiol. Lett. 242, 313-317. doi: 10.1016/j.femsle.2004.11.022

te Giffel, M. T., Wagendorp, A., Herrewegh, A., and Driehuis, F. (2002). Bacterial spores in silage and raw milk. Antonie Van Leeuwenhoek 81, 625-630. doi: 10.1023/A:1020578110353

Teh, K. H., Flint, S., Palmer, J., Andrewes, P., Bremer, P., and Lindsay, D. (2014). Biofilm- An unrecognised source of spoilage enzymes in dairy products? Int. Dairy J. 34, 32-40. doi: 10.1016/j.idairyj.2013.07.002

Teixeira, P., and Rodrigues, D. (2014). "Antibiofilm strategies in the food industry," in Antibiofilm Agents Springer Series on Biofilms, eds K. P. Rumbaugh and I. Ahmad (Berlin: Springer-Verlag), 359-381. doi: 10.1007/978-3-642-538339_16

Thorsen, L., Hansen, B. M., Nielsen, K. F., Hendriksen, N. B., Phipps, R. K., and Budde, B. B. (2006). Characterization of emetic Bacillus weihenstephanensis, a new cereulide-producing bacterium. Appl. Environ. Microbiol. 72, 5118-5121. doi: 10.1128/AEM.00170-06

Tolle, A. (1980). "The microflora of the udder," in Factors Influencing the Bacteriological Quality Of Raw Milk, International Dairy Federation Bulletin, Document 120, 4. 
Tominaga, T., An, S.-Y., Oyaizu, H., and Yokota, A. (2009). Sporosarcina luteola sp. nov. isolated from soy sauce production equipment in Japan. J. Gen. Appl. Microbiol. 55, 217-223. doi: 10.2323/jgam.55.217

Turnbull, P. C., Jackson, P. J., Hill, K. K., Keim, P., Kolstø, A. B., and Beecher, D. J. (2002). 'Longstanding taxonomic enigmas within the 'Bacillus cereus group' are on the verge of being resolved by far-reaching molecular developments: forecasts on the possible outcome by an ad hoc team," in Applications and Systematics of Bacillus and Relatives, eds R. Berkeley, M. Heyndrickx, N. Logan, and P. De Vos (Oxford: Blackwell Publishing), 23-36.

Vaerewijck, M., De Vos, P., Lebbe, L., Scheldeman, P., Hoste, B., and Heyndrickx, M. (2001). Occurrence of Bacillus sporothermodurans and other aerobic spore-forming species in feed concentrate for dairy cattle. J. Appl. Microbiol. 91, 1074-1084. doi: 10.1046/j.1365-2672.2001.014 77. $\mathrm{x}$

Vandamme, E. J., and Miedzybrodzki, R. (2013). Phage therapy and phage control: to be revisited urgently! J. Chem. Technol. Biotechnol. 89, 329-333. doi: $10.1002 /$ jctb. 4245

Van Houdt, R., and Michiels, C. W. (2010). Biofilm formation and the food industry, a focus on the bacterial outer surface. J. Appl. Microbiol. 109, 11171131. doi: 10.1111/j.1365-2672.2010.04756.x

Vedamuthu, E. (1992). The yogurt story: past, present and future. III. Dairy Food Environ. Sanit. 11, 310-311.

Villamiel, M., Schutyserm, M. A. I., and De Jong, P. (2009). "8. novel methods of milk processing," in Milk Processing and Quality Management, ed. A. Y. Tamime (Hoboken, NJ, Blackwell Publishing Ltd.)

Vlková, H., Babák, V., Seydlová, R., Pavlík, I., and Schlegelová, J. (2008). Biofilms and hygiene on dairy farms and in the dairy industry: sanitation chemical products and their effectiveness on biofilms- a review. Czech J. Food Sci. 26, 309-323.

Walsh, D., Molloy, C., Iversen, C., Carroll, J., Cagney, C., Fanning, S., et al. (2011). Survival characteristics of environmental and clinically derived strains of Cronobacter sakazakii in infant milk formula (IMF) and ingredients. J. Appl. Microbiol. 110, 697-703. doi: 10.1111/j.1365-2672.2010.0 4921.x

Walton, M. (2008). “1. Principles of cleaning-in-place (CIP),” in Cleaning-In-Place: Dairy, Food and Beverage Operations, 3rd Edn, ed. A. Y. Tamime (Hoboken, NJ: Blackwell Publishing Ltd.).

Watterson, M. J., Kent, D. J., Boor, K. J., Wiedmann, M., and Martin, N. H. (2014). Evaluation of dairy powder products implicates thermophilic sporeformers as the primary organisms of interest. J. Dairy Sci. 97, 2487-2497. doi: 10.3168/jds.2013-7363

White, J. C., and Rabe, G. O. (1970). Evaluating the use of nitric acid as a detergent in dairy cleaned-in-place systems. J. Milk Food Technol. 33, 25-28.

Wiencek, K. M., Klapes, N. A., and Foegeding, P. M. (1991). Adhesion of Bacillus spores to inanimate materials: effects of substratum and spore hydrophobicity. Biofouling 3, 139-149. doi: 10.1080/08927019109378168

Wolfgang, W. J., Coorevits, A., Cole, J. A., De Vos, P., Dickinson, M. C., Hannett, G. E., et al. (2012). Sporosarcina newyorkensis sp. nov. from clinical specimens and raw cow's milk. Int. J. Syst. Evol. Microbiol. 62, 322-329. doi: 10.1099/ijs.0.030080-0
Xu, D., and Côté, J. C. (2003). Phylogenetic relationships between Bacillus species and related genera inferred from comparison of $3^{\prime}$ end $16 \mathrm{~S}$ rDNA and $5^{\prime}$ end 16S-23S ITS nucleotide sequences. Int. J. Syst. Evol. Microbiol. 53(Pt 3), 695-704. doi: 10.1099/ijs.0.02346-0

Xu, J., Bigelow, T. A., Halverson, L. J., Middendorf, J. M., and Rusk, B. (2012). Minimization of treatment time for in vitro $1.1 \mathrm{MHz}$ destruction of Pseudomonas aeruginosa biofilms by high-intensity focused ultrasound. Ultrasonics 52, 668-675. doi: 10.1016/j.ultras.2012.01.013

Yoo, J.-A., Hardin, M. T., and Chen, X. D. (2006). The influence of milk composition on the growth of Bacillus stearothermophilus. J. Food Eng. 77, 96-102. doi: 10.1016/j.jfoodeng.2005.06.053

Yoo, J. G., Chang, J.-H., Kim, S.-Y., Ji, J.-Y., Hong, S.-W., Park, B.-Y., et al. (2014). Analysis of emetic toxin production by Bacillus species using cellular cytotoxicity, molecular, and chromatographic assays. Biotechnol. Bioprocess. Eng. 19, 978-983. doi: 10.1007/s12257-014-0574-7

Yoon, J.-H., Lee, K.-C., Weiss, N., Kho, Y. H., Kang, K. H., and Park, Y.-H. (2001). Sporosarcina aquimarina sp. nov., a bacterium isolated from seawater in Korea, and transfer of. Bacillus globisporus (Larkin and Stokes 1967), Bacillus psychrophilus (Nakamura 1984) and Bacillus pasteurii (Chester 1898) to the genus Sporosarcina as Sporosarcina globispora comb. nov., Sporosarcina psychrophila comb. nov. and Sporosarcina pasteurii comb. nov., and emended description of th. Int. J. Syst. Evol. Microbiol. 51, 1079-1086.

Yu, Y., Xin, Y.-H., Liu, H.-C., Chen, B., Sheng, J., Chi, Z.-M., et al. (2008). Sporosarcina antarctica sp. nov., a psychrophilic bacterium isolated from the Antarctic. Int. J. Syst. Evol. Microbiol. 58, 2114-2117. doi: 10.1099/ijs.0.65838-0

Yuan, D.-D., Liu, G.-C., Ren, D.-Y., Zhang, D., Zhao, L., Kan, C.-P., et al. (2012). A survey on occurrence of thermophilic bacilli in commercial milk powders in China. Food Control 25, 752-757. doi: 10.1016/j.foodcont.2011.12.020

Zaman, M. Z., Bakar, F. A., SelaMat, J., and Bakar, J. (2010). Occurrence of biogenic amines and amines degrading bacteria in fish sauce. Czech J. Food Sci. 28, 440-449.

Zhang, W., and Lu, Z. (2015). Phylogenomic evaluation of members above the species level within the phylum Firmicutes based on conserved proteins. Environ. Microbiol. Rep. 7, 273-281. doi: 10.1111/1758-2229.12241

Zhao, Y., Caspers, M. P., Metselaar, K. I., de Boer, P., Roeselers, G., Moezelaar, R., et al. (2013). Abiotic and microbiotic factors controlling biofilm formation by thermophilic sporeformers. Appl. Environ. Microbiol. 79, 5652-5660. doi: 10.1128/AEM.00949-13

Conflict of Interest Statement: The authors declare that the research was conducted in the absence of any commercial or financial relationships that could be construed as a potential conflict of interest.

Copyright (C) 2015 Gopal, Hill, Ross, Beresford, Fenelon and Cotter. This is an openaccess article distributed under the terms of the Creative Commons Attribution License (CC BY). The use, distribution or reproduction in other forums is permitted, provided the original author(s) or licensor are credited and that the original publication in this journal is cited, in accordance with accepted academic practice. No use, distribution or reproduction is permitted which does not comply with these terms. 